\title{
Review \\ Transcriptional Regulation of Hepatic Autophagy by Nuclear Receptors
}

\author{
Eun Young Kim ${ }^{1}$ and Jae Man Lee ${ }^{1,2, *(\mathbb{D})}$ \\ 1 Department of Biochemistry and Cell Biology, Cell and Matrix Research Institute, School of Medicine, \\ Kyungpook National University, Daegu 41944, Korea; key11@knu.ac.kr \\ 2 BK21 FOUR KNU Biomedical Convergence Program, Department of Biomedical Science, \\ Kyungpook National University, Daegu 41944, Korea \\ * Correspondence: jaemanlee@knu.ac.kr; Tel.: +82-53-420-4826
}

check for

updates

Citation: Kim, E.Y.; Lee, J.M.

Transcriptional Regulation of Hepatic Autophagy by Nuclear Receptors. Cells 2022, 11, 620. https://doi.org/ $10.3390 /$ cells 11040620

Academic Editor: Fulvio Reggiori

Received: 23 January 2022

Accepted: 8 February 2022

Published: 10 February 2022

Publisher's Note: MDPI stays neutral with regard to jurisdictional claims in published maps and institutional affiliations.

Copyright: () 2022 by the authors Licensee MDPI, Basel, Switzerland. This article is an open access article distributed under the terms and conditions of the Creative Commons Attribution (CC BY) license (https:// creativecommons.org/licenses/by/ $4.0 /)$.

\begin{abstract}
Autophagy is an adaptive self-eating process involved in degradation of various cellular components such as carbohydrates, lipids, proteins, and organelles. Its activity plays an essential role in tissue homeostasis and systemic metabolism in response to diverse challenges, including nutrient depletion, pathogen invasion, and accumulations of toxic materials. Therefore, autophagy dysfunctions are intimately associated with many human diseases such as cancer, neurodegeneration, obesity, diabetes, infection, and aging. Although its acute post-translational regulation is well described, recent studies have also shown that autophagy can be controlled at the transcriptional and post-transcriptional levels. Nuclear receptors (NRs) are in general ligand-dependent transcription factors consisting of 48 members in humans. These receptors extensively control transcription of a variety of genes involved in development, metabolism, and inflammation. In this review, we discuss the roles and mechanisms of NRs in an aspect of transcriptional regulation of hepatic autophagy, and how the NR-driven autophagy pathway can be harnessed to treat various liver diseases.
\end{abstract}

Keywords: autophagy; macroautophagy; nuclear receptor; liver

\section{Introduction}

Autophagy is a conserved intracellular degradation process delivering cytoplasmic materials to the lysosome. Unlike the ubiquitin-mediated proteasomal system (UPS) typically degrading short-lived proteins, autophagy involves a bulk process that degrades long-lived proteins, carbohydrates, lipids, and worn-out organelles, including ribosomes, peroxisomes, mitochondria, endoplasmic reticulum, and even nucleus [1-5]. In this way, autophagy is considered to promote nutrient recycling upon starvation and fulfill cellular energy demands [6]. There are three main types of autophagy: macroautophagy, microautophagy, and chaperone-mediated autophagy. Macroautophagy involves the formation of a double-membrane vesicle called an autophagosome (AP), which enables the engulfment of cytoplasmic materials and then fuses with lysosomes to generate autolysosomes (AL) where cargo molecules are degraded by lysosomal acidic hydrolases [1-3]. Microautophagy involves a direct engulfment of cytoplasmic cargo materials into lysosomes for their degradation [7-9]. In chaperone-mediated autophagy (CMA), cytosolic cargo proteins containing a specific targeting motif (KFERQ-like sequence) that is recognized by heat shock cognate 70 protein (HSC 70) are translocated into the lysosome through the lysosomal-associated transmembrane receptor 2A (LAMP-2A) for degradation $[10,11]$ (Figure 1). 

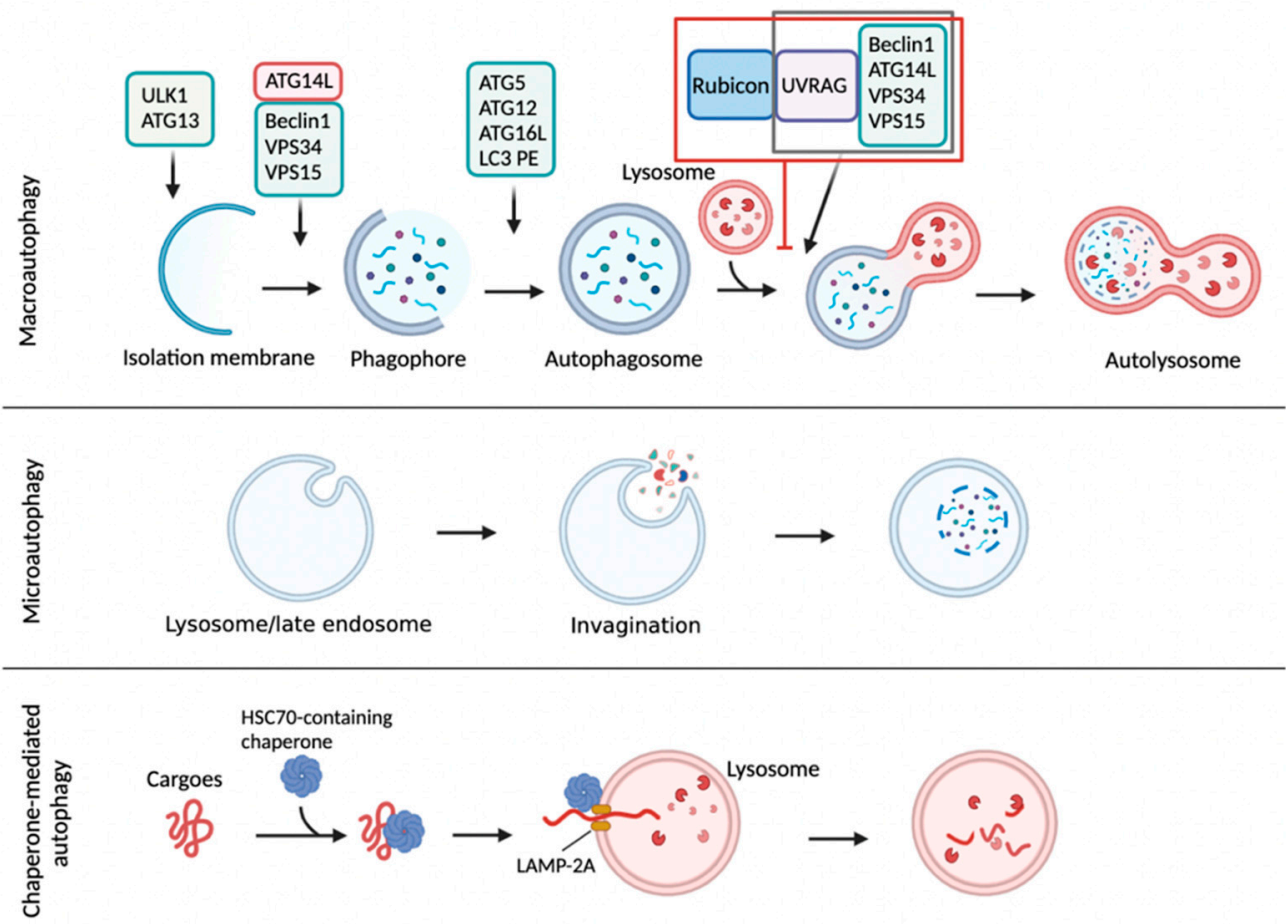

Figure 1. Autophagy is a catabolic process degrading cytoplasmic molecules, aggregated proteins, and infectious pathogens. There are three major types of autophagy: macroautophagy, microautophagy, and chaperone-mediated autophagy (CMA). Macroautophagy is initiated from an isolation membrane (also termed phagophore) to gather soluble materials and organelles for autophagosome formation. Autophagosomes fuses with lysosomes to form autolysosomes where cytoplasmic cargo molecules are finally degraded by lysosomal acidic hydrolases. Rubicon is a Beclin1-interacting protein involved in autophagy initiation and autophagosome maturation. Rubicon could directly bind to Class III PI3K-Beclin1-UVRAG complex for inhibition of autolysosome formation. In microautophagy, inward invagination of the lysosomal membrane or late endosome membrane engulfs small cytosolic components for their degradation. Lastly, CMA is mediated by a direct translocation of cargo proteins but not by the membrane reconstruction shown in macroautophagy or microautophagy. The cytosolic chaperone protein heat shock cognate 70 (Hsc70) and cochaperones recognize the specific pentameric peptide sequence (a KFERQ-like motif). The cytosolic proteins containing the KFERQ-like pentapeptide captured by Hsc70-cochaperone are translocated into the lysosome through a lysosomal associated membrane protein 2A (LAMP-2A) receptor on lysosomal membrane. This schematic diagram was created in BioRender.com (accessed on 20 January 2022).

Nuclear receptor superfamily functions as transcriptional switches recognizing information of external changes and then delivering it to the genome, resulting in alterations of gene expression. They are either ligand-dependent or -independent transcription factors that play key roles in almost every mammalian physiology. Dysfunctions of nuclear receptor (NR) signaling pathways often become culprits that lead to many human diseases including liver diseases [12-18]. For a long time, autophagy regulation has been considered to exclusively occur in cytoplasm. This notion has been further supported by the findings that erythrocytes, enucleated cells, are still able to form autophagosomes [19,20]. Nevertheless, accumulated literature during the last two decades suggests that transcriptional and post-transcriptional events in the nucleus are also important for autophagy regulation. Since Christian de Duve initially described autophagy in rat hepatocytes upon the treatment of glucagon, a fasting-induced pancreatic hormone, the liver is the major organ where autophagy has been studied. Moreover, many nuclear receptors responding to presence or absence of nutrients play essential roles in the regulation of liver functions. In this review, we aim to summarize the transcriptional regulation of hepatic autophagy by NRs and 
to discuss how these regulations can contribute to the development of novel therapeutic strategies to treat liver diseases.

\section{Overview of Autophagy}

Autophagy is an evolutionarily conserved degradation process delivering intracellular cargo molecules to lysosomes. These cargos include glycogen, lipid droplets, aggregated proteins, membrane-enclosed organelles, and infected parasites [1,21,22]. Although most cells and tissues maintain a constant level of basal autophagy, numerous stimuli tremendously elevate autophagy activity. For example, autophagy can be markedly induced by physiological perturbations such as nutrient and growth factor deprivation, hypoxia, high temperature, high density conditions, and exercise. It is also activated by the endocrine hormones glucagon and FGF21, and diverse chemical reagents such as rapamycin, Torin, and AICAR. Many disease conditions, including cancer and muscle disease, are also known to have elevated levels of autophagy [23]. Although several types of autophagy have been reported based on different classifying criteria, macroautophagy is a primary form of autophagy, and it has been most intensively investigated so far compared with the two other forms of autophagy, called microautophagy and CMA (Figure 1). In most cells, there is a constitutive activity of macroautophagy, albeit at low levels, which contributes to constitutive turnover of cytosolic materials. This is considered as a basal autophagy activity. However, various cellular conditions, in particular nutrient deprivation, can markedly increase autophagy to stimulate the degradation of cytosolic substrates to generate energy and nutrient recycling. Two nutrient-sensitive kinases, mTORC1 and AMPK, rapidly respond to nutrient alterations and phosphorylate autophagy machinery proteins. In nutrient abundant status, mTORC1 phosphorylates two autophagy initiation proteins unc-51-like kinase 1 (ULK1) and ATG13, decreasing their autophagy initiation activity. In contrast, the absence of nutrients leads to inactivation of mTORC1 and subsequent activation of AMPK, which phosphorylates ULK1 and ATG13 on specific residues enhancing autophagy initiation. Next, in the nucleation step of autophagy, activated ULK1 complex increases the assembly of class III PI3K complex consisting of Beclin1, vacuolar protein sorting 15 (VPS15), VPS34, and ATG14L, to generate a local production of phosphatidylinositol 3-phosphate (PI3P) that is incorporated into the nucleated membrane of the autophagosome. In the maturation step, two ubiquitin conjugating systems are involved in autophagosome formation. The ATG12-ATG5-ATG16 complex is recruited to the autophagosome membrane and promotes a phosphatidylethanolamine (PE)-conjugation of microtubule-associated protein 1 light chain 3 (MAP1LC3, also known as LC3). This lipidated LC3 is required for the expansion of the autophagosome membrane. The resulting autophagosome then fuses with a lysosome, ultimately leading to the formation of an autolysosome where the autophagic cargos are degraded by lysosomal acidic hydrolases [24,25]. Rubicon could directly bind to Class III PI3K-Beclin1-UVRAG complex, resulting in the inhibition of autolysosome formation $[26,27]$. It is of interest to note that AL can also be made by an alternative pathway via a fusion of a lysosome with an amphisome, a vesicle created from a fusion between the AP and a late endosome (also known as multivesicular body) [28]. Degraded molecules within the AL are released into cytoplasm and recycled in the biosynthetic pathways to make new macromolecules or used for ATP production. In this way, autophagy is considered to link catabolism to anabolism $[21,29,30]$ (Figure 1).

The degradative function of autophagy also plays a critical role in the intracellular quality control of many components by removing unfolded, misfolded, or aggregated proteins, or damaged organelles. Therefore, its cellular functions are very versatile, ranging from eliminating superfluous organelles to providing building blocks for lipid and protein synthesis, and energy supplementation to removing abnormal proteins for a quality control mechanism. Autophagy functions as a host defense mechanism by destroying invasive pathogens and subsequently presenting pathogen-derived antigens on the plasma membrane [1]. It has been suggested that excessive autophagy may trigger certain types of cell death including apoptosis and entosis [31,32]. Beyond its cellular 
functions, autophagy has a broad impact on mammalian pathophysiology including embryonic development, innate and adaptive immunity, neurodegenerative disease, cancer, heart disease and skeletal pathogenesis, ageing, and metabolic diseases [2,33-36]. On the contrary to a previous idea that autophagy may be a nonselective degradation process, numerous selective autophagies have been discovered depending on their cargo molecules and organelles. These include aggrephagy for aggregated proteins, glycophagy for glycogen, lipophagy for lipid droplets, ferritinophagy for iron-bearing ferritins, ribophagy for ribosome, pexophagy for peroxisome, reticulophagy for endoplasmic reticulum, mitophagy for mitochondria, xenophagy for virus and bacteria, nucleophagy for nucleus, and so forth $[37,38]$.

Transcriptional regulation of autophagy was first observed in yeast where nitrogen starvation increased expression of autophagy gene $A p g 8 p$, the yeast homologue of mammalian LC3 [39]. During the last two decades, it has been demonstrated that many transcription factors, including NRs, induce the expression of autophagy genes, resulting in the enhancement of autophagy and degradation of unnecessary intracellular materials [40-43]. These findings paved the way for understanding autophagy regulation in the nucleus.

\section{Overview of Nuclear Receptor Superfamily}

As ligand-regulated transcription factors (TFs), NRs reside at the interface between environmental changes in cells and our genome, serving as an important linker between transcription and physiology. Thus, NRs play key roles in mammalian signaling because they can integrate diverse intra- and extracellular signals to initiate specific gene expressions for their relevant physiology. Owing to their unique characteristics in mammalian physiology, the activities of NRs are often affected by environmental stimuli that could produce ligands or sometimes modulate ligand production [14,44,45]. Moreover, NRs have a tremendous impact on most of mammalian physiology. Consequently, their dysfunctions are also associated with a broad range of human diseases, including metabolic diseases, cancer, immune disorders, cardiovascular diseases, and neurological diseases [45,46]. With a few exceptions, NRs usually consist of several domains: an N-terminal ligand-independent activation function 1 (AF1) motif, a highly conserved DNA-binding domain (DBD) with two zinc finger motifs, a flexible hinge domain, and a C-terminal less conserved ligand-binding domain (LBD) consisting of $12 \alpha$-helixes. Upon an agonist binding to the ligand-binding pocket of LBD, the helix 12 corresponding to ligand-dependent activation function 2 (AF2) motif undergoes a significant conformational change. This allows the exposure of a docking surface for coactivators that subsequently recruit more transcriptional machinery proteins to initiate the transcription of a given NR target gene [14].

In the human genome, there are 48 members of NRs that include classical endocrine receptors for steroid hormones, thyroid hormone, and fat soluble vitamins and their derivatives, adopted orphan receptors for fatty acids (FAs), phospholipids, cholesterol metabolites, bile acids (BAs), and heme, and orphan receptors whose ligands have not been discovered yet or may not exist at all [14] (Figure 2). Intensive research for nearly 40 years allows for enhancing our understanding of complex molecular mechanisms of an NR-driven transcriptional program. From these endless efforts, many NRs turn out to be valuable molecular targets for effective treatments in human diseases, which provide opportunities for developing better therapeutics with fewer side effects. 
Human Nuclear Receptor Superfamily : $\mathbf{4 8}$ members

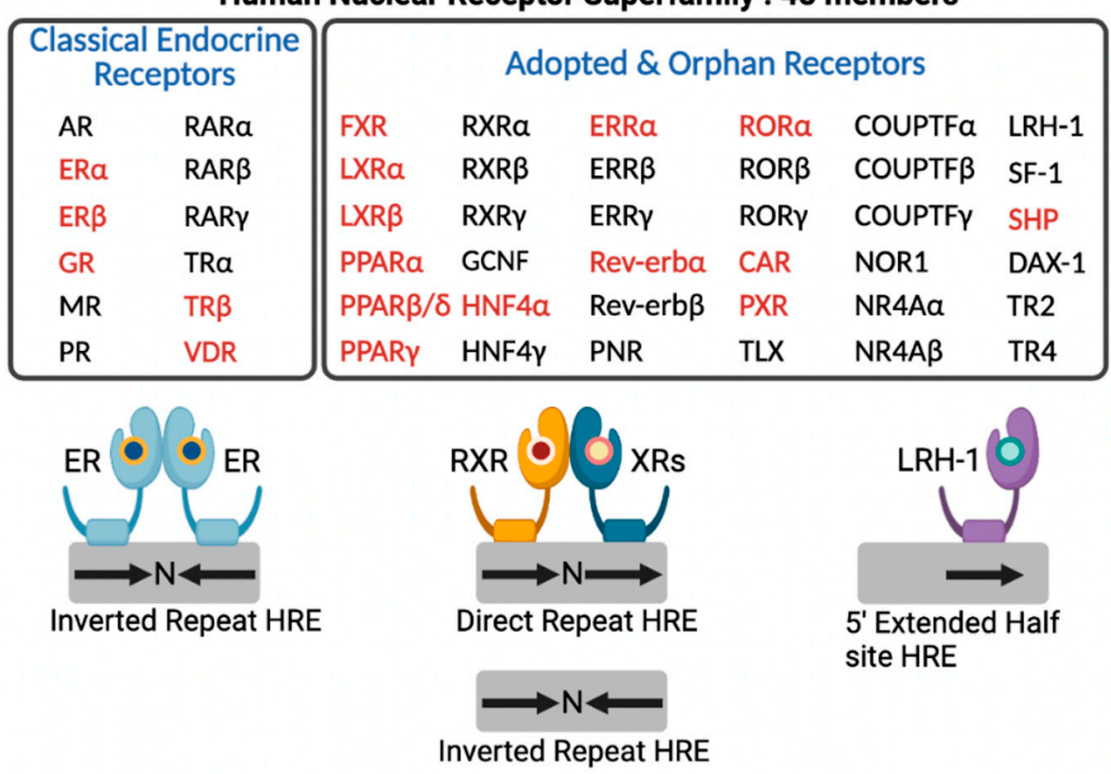

Figure 2. Human nuclear receptor superfamily. Human genome encodes 48 members of nuclear receptors (NRs). NRs are divided into two groups based on the source and type of their ligands. Classical endocrine receptors include steroid hormone receptors and RXR heterodimeric receptors. Adopted and orphan receptors include several receptors for dietary lipids, cholesterol derivatives, bile acids, phospholipids, and heme, and receptors with unknown ligands. The hormone response element (HRE) core sequence AGGTCA is represented by black arrows. $\mathrm{N}$ indicates any nucleotide between the half sites of HRE. Endocrine receptors usually bind as homodimers to palindromic DNA sequences (inverted repeats) separated by three nucleotides (IR3). Some NRs bind DNA as heterodimers with RXR to direct repeats separated by zero to six nucleotides (DR0-6) or to inverted repeats spaced by zero or one nucleotide (IR0-1). A few NRs interact with DNA as monomers to HRE containing a three-nucleotide 5 '-extension. NRs shown in red colored letters are known to regulate hepatic autophagy, which is discussed in this review. This schematic diagram was created in BioRender.com (accessed on 20 January 2022).

\section{Classical Endocrine Receptors}

\subsection{Glucocorticoid Receptor (GR)}

GR plays an important role in the regulation of genes involved in glucose homeostasis, inflammation, and stress response. GR activity can be potently modulated in response to glucocorticoids and synthetic ligands (e.g., dexamethasone, RU486, compound A, etc.), which are wildly used to treat inflammatory diseases. In addition to the roles of transactivation, GR has been shown to repress target gene expression via diverse mechanisms including transrepression and binding to non-canonical GR-binding site $[47,48]$. In particular, in the fasted liver, it has been shown that there are significant crosstalks between GR and other DNA-binding transcription factors and coactivators, including hepatocyte nuclear factor $4 \alpha(\mathrm{HNF} 4 \alpha)$, cAMP-responsive element-binding protein 1 (CREB), peroxisome proliferator-activated receptor $\alpha(\operatorname{PPAR} \alpha)$, and peroxisome proliferator-activated receptor $\gamma$ coactivator $1 \alpha($ PGC- $1 \alpha)[49,50]$.

Regulation of hepatic autophagy by the modulation of GR functions has not been extensively studied in vivo so far. However, it has been reported that dexamethasone exposure to pregnant rats leads to inhibited proliferation and to dysplasia in offspring livers. Molecular mechanisms have been proposed that dexamethasone-activated GR increases FOXO1 mRNA and protein levels, which in turn induce hepatic autophagy in fetal livers [51]. In this context, the elevated autophagy activity by the GR-FOXO1 axis seems to be detrimental for normal development of fetal liver. 


\subsection{Estrogen Receptors $(E R \alpha \mathcal{E} E R \beta)$}

Estrogens play a pivotal role in the developmental processes of reproductive systems in females. Among two isoforms, $\mathrm{ER} \alpha$ has been most studied in the liver. Estrogen binding enables dissociation of ERs from cytoplasmic heat shock protein 90 (HSP90), which is then translocated into the nucleus [52]. To control target gene expression, ERs bind to its response elements and then recruit coregulators. ERs have also been demonstrated to indirectly regulate target gene expression in a tether mechanism via other DNA-binding transcription factors such as members of the Forkhead box (FOX) family and activator protein 1 (AP-1) [53-55]. In the liver, the tethering mechanisms seem to be dominant due to the identification of AP-1 occupancies for ER $\alpha$-binding sites [56]. ER activation with estradiol treatment has been reported to repress lipid biosynthesis and gluconeogenesis via the interaction with STAT3 $[57,58]$.

Estrogen and ERs have been shown to have a strong gender bias in the autophagy regulation of Japanese medaka. Estrogen induces hepatic autophagy in female fish but suppresses it in male fish. This study further demonstrated that a specific ER isoform has a different mechanism for autophagy regulation. ER $\alpha$ induces hepatic autophagy via a hexokinase $2 / \mathrm{AMPK} / \mathrm{mTOR}$ pathway, whereas ER $\beta 2$ increases autophagy in a $\mathrm{Ca}^{2+}$ dependent manner [59].

\subsection{Thyroid Receptors (TR $\alpha$ E TR $\beta$ )}

Thyroid hormone regulates cell growth, development, differentiation, and metabolism. T3, the major form of active thyroid hormone, can dynamically regulate transcription of target genes involved in lipid, glucose, and amino acid metabolism [60-62]. Among two isoforms, TR $\beta$ is predominantly expressed in the liver. TR forms a heterodimeric complex with RXR. Intriguingly, LXR and PPAR $\alpha$ have been shown to compete with TR for binding to thyroid hormone response elements [63]. Without its agonist ligands, TR represses target gene expression by recruiting a corepressor complex containing nuclear receptor corepressor (NCoR) and histone deacetylase 3 (HDAC3) [64,65]. However, upon binding to thyroid hormones, conformational changes of TR lead to dissociation of corepressors and then recruit coactivators, resulting in increasing chromatin accessibility and target gene expression [66]. It has been suggested that TR activation controls lipid metabolism via diverse mechanisms, contributing to the improvement of non-alcoholic steatosis and inflammation in rodents $[67,68]$.

Thyroid hormones are important for enhancing oxidative metabolism in the liver. The Yen laboratory has intensively studied to define roles of TR on hepatic autophagy. They have shown that T3 treatment drastically increases lipophagy, a selective autophagy for lipid droplets in hepatocyte- or hepatoma-driven cell lines and mouse liver. This allows released free fatty acids to be delivered to mitochondria for fatty acid oxidation (FAO) [69]. They have also reported that T3 treatment in human liver cells increases mRNA and protein levels of chromosome 19 open reading frame 80 (C19orf80) gene that promotes autophagy activity by facilitating a completion of autolysosome maturation [70]. Moreover, it has been demonstrated that T3 induces mitophagy, a selective autophagy for mitochondria through the oxidative phosphorylation (OXPHOS)-mediated reactive oxygen species (ROS) axis. ROS induction by T3 increases phosphorylation of 5'AMP-activated protein kinase $(\mathrm{AMPK})$ via the activation of calcium/calmodulin-dependent protein kinase kinase $2, \beta$ (CAMKK2), which in turn leads to phosphorylation of ULK1, resulting in initiation of mitophagy. This study suggests that T3-mediated mitophagy is important not only for degrading damaged organelles but also for maintaining efficient OXPHOS [71]. An alternative pathway for TR-driven mitophagy induction has also been reported. There is a cooperative activity between $\operatorname{TR} \beta$ and estrogen-related receptor $\alpha(E R R \alpha)$ to regulate mitophagy. Many genes involved in mitochondrial metabolism are co-regulated by both NRs. It has been demonstrated that thyroid hormone-activated TR $\beta$ increases ERR $\alpha$ expression via the induction of $P g c-1 \alpha$ gene. ERR $\alpha$ now elevates ULK1 expression, which in turn leads to the activation of FUNDC1, a docking protein for LC3B-II. This complex 
pathway ultimately activates mitophagy in response to thyroid hormone treatment [72] Finally, the Yen group has demonstrated that thyroid hormone levels significantly affect the development of hepatocellular carcinoma (HCC) through the modulation of aggrephagy, a selective autophagy for aggregated proteins. They have shown that thyroid hormone administration suppresses diethylnitrosamine (DEN)-treated HCC development in mice. Molecular mechanisms have been suggested that T3 increases death-associated protein kinase 2 (DAPK2) expression, which subsequently leads to phosphorylation of sequestosome 1 (p62/SQSTM1). This phospho-p62 promotes autophagic clearance of aggregated proteins, resulting in the alleviation of DEN-driven hepatocarcinogenesis [73]. Overall, thyroid hormone-activated TR $\beta$ has a profound impact on the induction of several types of hepatic autophagy including lipophagy, mitophagy, and aggrephagy. This may contribute to increased FAO and mitochondrial biogenesis, and decreased cancer promotion in the liver.

\subsection{Vitamin D Receptor (VDR)}

VDR is a key transcription factor for calcium homeostasis and skeletal health [74,75]. VDR is primarily activated by its endogenous ligands, an active form of vitamin D $\left(1,25(\mathrm{OH})_{2} \mathrm{D}_{3}\right)$ and bile acids lithocholic acid and its derivatives [76,77]. VDR forms a homodimer or heterodimer with RXR to control target gene expression along with coregulator complexes $[78,79]$. Defining a physiological role of vitamin $\mathrm{D}$ in the regulation of liver function has been limited due to the low expression levels of $V d r$ gene [80]. However, it has been elegantly demonstrated that there are robust $V d r$ expressions in other types of nonparenchymal cells, such as hepatic stellate cells (HSCs) and Kupffer cells, although hepatocytes express very low levels of $V d r[81,82]$. In HSCs, VDR activation has been reported to potently repress TGF $\beta$-induced profibrotic gene expression by antagonizing SMADdependent transcriptional programs, suggesting that targeting VDR with less calcemic ligands might be beneficial for the prevention and treatment of liver fibrosis [82].

It has been known that $1,25(\mathrm{OH})_{2} \mathrm{D}_{3}$ treatment significantly attenuates hepatic steatosis [83]. The Jiang laboratory has demonstrated that $1,25(\mathrm{OH})_{2} \mathrm{D}_{3}$ activates autophagy by inducing Atg16l1 expression, which also has anti-inflammatory effects and improved lipid profiles [84]. Moreover, calcitriol administration was able to reduce ethanol-induced hepatotoxicity via the induction of AMPK/mTOR-mediated autophagy. VDR activation by calcitriol treatment increases the formation of APs and ALs, upregulates $L c 3 b$ and Atg5, and promotes degradation of p62, leading to mitophagy [85]. The studies of classical endocrine nuclear receptors for hepatic autophagy regulation are summarized in Table 1.

Table 1. Classical endocrine nuclear receptors coordinate hepatic autophagy.

\begin{tabular}{|c|c|c|c|c|c|}
\hline NRs & $\begin{array}{l}\text { Ligand/ } \\
\text { Activator }\end{array}$ & Study Model & Autophagy & Mechanism of Action & Refs. \\
\hline GR & Dexamethasone & Rat fetal liver & $\uparrow$ & $\begin{array}{c}\text { GR activation } \uparrow \rightarrow \text { FoxO1 gene } \uparrow \rightarrow \\
\text { autophagy- related genes } \uparrow \rightarrow \text { proliferation } \\
\text { of fetal liver } \downarrow\end{array}$ & [51] \\
\hline \multirow{2}{*}{$\mathrm{ER} \alpha$} & E2 & \multirow{3}{*}{$\begin{array}{c}\text { Japanese Medaka } \\
\text { fish }\end{array}$} & $\begin{array}{c}\uparrow(\text { Female) } \\
\downarrow \text { (Male) }\end{array}$ & & \multirow{3}{*}{ [59] } \\
\hline & - & & $\uparrow$ & $\mathrm{HK} 2 \downarrow \rightarrow \mathrm{AMPK} \uparrow \rightarrow \mathrm{mTOR} \downarrow \rightarrow \mathrm{ULK} 1 \uparrow$ & \\
\hline $\mathrm{ER} \beta 2$ & E2 & & $\uparrow$ & $\mathrm{Ca}^{2+}$ dependent manner & \\
\hline
\end{tabular}


Table 1. Cont.

\begin{tabular}{|c|c|c|c|c|c|}
\hline NRs & $\begin{array}{l}\text { Ligand/ } \\
\text { Activator }\end{array}$ & Study Model & Autophagy & Mechanism of Action & Refs. \\
\hline \multirow{4}{*}{$\operatorname{TR} \beta$} & \multirow{4}{*}{ T3 } & $\begin{array}{l}\text { HepG2, AML12, } \\
\text { Hep3B, Hur7, } \\
\text { mouse liver, } \\
\text { human liver cells }\end{array}$ & $\uparrow$ & $\begin{array}{c}\text { C19orf80 gene } \uparrow \rightarrow \mathrm{AL} \uparrow \rightarrow \text { lipophagy } \uparrow \rightarrow \\
\text { FFA } \uparrow \rightarrow \text { FAO } \uparrow\end{array}$ & {$[69,70]$} \\
\hline & & $\begin{array}{l}\text { HepG2, mouse } \\
\text { liver }\end{array}$ & $\uparrow$ & $\begin{array}{l}\text { OXPHOS } \uparrow \rightarrow \text { Camkk2 gene } \uparrow \rightarrow \operatorname{ROS} \uparrow \rightarrow \\
\text { AMPK phosphorylation } \uparrow \rightarrow \mathrm{ULK} 1 \\
\text { phosphorylation } \uparrow \rightarrow \text { mitophagy } \uparrow\end{array}$ & [71] \\
\hline & & $\begin{array}{l}\text { HepG2, mouse } \\
\text { liver }\end{array}$ & $\uparrow$ & $\begin{array}{l}\mathrm{TR} \beta \rightarrow \text { Pgc-1 } \alpha \text { gene } \uparrow \rightarrow \text { Err } \alpha \text { gene } \uparrow \rightarrow \text { Ulk1 } \\
\text { gene } \uparrow \rightarrow \text { FUNDC1-LC3B-II } \rightarrow \text { mitophagy } \uparrow\end{array}$ & [72] \\
\hline & & $\begin{array}{l}\text { DEN-treated HCC } \\
\text { in mice }\end{array}$ & $\uparrow$ & $\begin{aligned} \text { Dapk2 gene } \uparrow & \rightarrow \text { p62 phosphorylation } \uparrow \rightarrow \\
& \text { aggrephagy } \uparrow\end{aligned}$ & [73] \\
\hline \multirow[b]{2}{*}{ VDR } & $1,25(\mathrm{OH})_{2} \mathrm{D}_{3}$ & $\begin{array}{l}\text { HepG2, HFD-fed } \\
\text { mice livers }\end{array}$ & $\uparrow$ & Atg16l1 gene $\uparrow$ & [84] \\
\hline & Calcitriol & $\begin{array}{l}\text { LO2, HepG2, } \\
V d r^{-/-} \text {mice, } \\
\text { mouse hepatocytes }\end{array}$ & $\uparrow$ & $\begin{array}{c}\mathrm{AMPK} \uparrow \rightarrow \mathrm{mTOR} \downarrow \rightarrow \mathrm{LC} 3 \mathrm{~B}-\mathrm{II} \& \mathrm{ATG} 5 \uparrow \\
\mathrm{AP} \& \mathrm{AL} \uparrow \rightarrow \mathrm{p} 62 \downarrow \rightarrow \text { mitophagy } \uparrow\end{array}$ & [85] \\
\hline & & \multicolumn{4}{|c|}{$\begin{array}{l}\text { E2, Estrogen; AMPK, AMP-activated protein kinase; mTOR, mammalian target of rapamycin; HK2, hexokinase } \\
\text { 2; ULK1, unc-51-like kinase 1; FFA, free fatty acid; FAO, fatty acid oxidation; ROS, reactive oxygen species; } \\
\text { CaMKK2, calcium/calmodulin dependent protein kinase kinase 2; FUNDC1, Fun14 domain containing 1; DAPK2, } \\
\text { death associated protein kinase 2; HCC, hepatocellular carcinoma; HFD, high-fat diet; } \uparrow \text {, increase; } \rightarrow \text {, promote; } \\
\downarrow \text {, decrease. }\end{array}$} \\
\hline
\end{tabular}

\section{Adopted and Orphan Receptors}

\subsection{Farnesoid X Receptor (FXR)}

FXR is a nuclear bile acid receptor and forms a heterodimeric complex with RXR, predominantly binding to inverted repeat 1 response elements of target genes. It plays a key role in bile acid homeostasis and its related lipid, glucose, and amino acid metabolism [86-90]. It has also been demonstrated that FXR is necessary for normal liver regeneration of wild-type mice, and for the beneficial effects of vertical sleeve gastrectomy on obese mice [91-94]. Several bile acids have been suggested as endogenous ligands for the regulation of FXR functions in enterohepatic tissues [95-100]. Natural antagonist and synthetic agonist ligands have also been reported and are currently intensively studied for clinical applications [101-105]. In these metabolic tissues, FXR has been suspected to be activated by returning bile acids in the process of enterohepatic circulation, indicating that FXR potently responds to a feeding status $[88,106,107]$. Therefore, FXR-mediated transcriptional programs have a significant impact on hepatic energy metabolism during postprandial periods [108,109].

The initial report that links FXR to autophagy regulation was that the treatment of GW4064, a synthetic FXR agonist, increases Sqstm1 expression in mouse ileum, but not in mouse liver. The Guo laboratory has demonstrated that $p 62$ is a direct FXR target gene and suggested that this FXR-mediated p62 induction might provide a protective mechanism against tumorigenesis and inflammation [110]. The Ding laboratory has also shown that treatments of several bile acids induce accumulation of p62 proteins in mouse primary hepatocytes and livers, indicative of impaired autophagic flux. FXR activation in response to bile acids suppresses expression of the $R a b 7$ gene, whose protein is known to promote a fusion process of AP and lysosome to make AL [111]. Consecutively, two laboratories have simultaneously reported that hepatic FXR activation is sufficient for suppressing autophagy even in a fasted liver, and that FXR is required for autophagy suppression in a fed state of the liver. In these studies, FXR represses expression of many autophagy-related genes that can be upregulated by fasting-activated transcription factors such as PPAR $\alpha$ and CREB [112-114]. Mechanistically, both FXR and PPAR $\alpha$ can compete with each other to bind direct repeat 1 (DR1) response elements in the regulatory regions of autophagy-related 
genes. Moreover, FXR has also been shown to transrepress autophagy-related gene expression by disrupting a CREB-CRTC2 complex [112]. Consistent with these results, increased expressions of autophagy-related genes were observed in the liver of both Fxr and Shp double-knockout (FS DKO) as well as liver-specific $F x r$ and $S h p$ double-knockout $\left(F S^{L D K O}\right.$ ) mice, suggesting that FXR acts as a negative transcription factor in this context [115]. In contrast to this, an acute ethanol treatment decreased expression of various autophagyrelated genes and FoxO3 target genes in $F x r$ knockout $\left(F x r^{--}\right)$mice. It has been suggested that increased AKT activity in the liver of $\mathrm{Fxr}^{-/}$mice phosphorylates FoxO3, facilitating its cytoplasmic retention. These mechanisms seem to be associated with exacerbated hepatotoxicity and steatosis upon ethanol consumption [116]. Recently, a novel mechanism by which FXR suppresses autophagy in human cholestatic conditions has been reported. The Wagner laboratory has demonstrated that elevated bile acid levels in human cholestasis induce FXR-mediated autophagy impairments via the upregulation of Rubicon, which may inhibit a final fusion process between APs and lysosomes. Ursodeoxycholic acid (UDCA), a 7-OH epimer of CDCA, previously proposed as an FXR antagonist, improved human cholestasis by decreasing Rubicon expression, providing a novel therapeutic mechanism for cholestatic patients [117-119]. Overall, FXR activation potently inhibits hepatic autophagy by controlling expression of many autophagy-related genes, and autophagy induction by antagonizing FXR activity may be useful for treatment of certain liver diseases.

\subsection{Peroxisome Proliferator-Activated Receptors (PPAR $\alpha, P P A R \beta / \delta, \mathcal{E} P P A R \gamma$ )}

This subfamily contains three isoforms, and each member forms a heterodimer with RXR $[120,121]$. This receptor complex binds to peroxisome proliferation response elements (PPRE) of target genes [122,123]. Among PPREs, the most enriched response element is a direct repeat 1 (DR1) sequence [113]. PPAR $\alpha$ was first identified due to its ability to induce peroxisome proliferation in response to $\mathrm{Wy}-14,643$ [124]. Peroxisomes contribute to $\mathrm{FAO}$, and their proliferation results in hepatomegaly and tumorigenesis in rodents, but not in humans $[46,124]$. Subsequently, two additional isoforms known as PPAR $\gamma$ and PPAR $\beta / \delta$ were discovered [125-127]. These NRs are activated by dietary fatty acids and their metabolic derivatives, and phospholipids, thereby serving as lipid sensors in our body. PPAR $\alpha$ and PPAR $\gamma$ are mainly expressed in liver and adipose tissue, respectively, whereas PPAR $\beta / \delta$ is ubiquitously expressed throughout various tissues. Both PPAR $\alpha$ and PPAR $\beta$ / $\delta$ play an essential role in FAO and/or thermogenesis $[124,125,128]$. In contrast, PPAR $\gamma$ is famous for being a master regulator for adipogenesis and peripheral insulin sensitivity $[127,129]$. The importance of these receptors in pathophysiology is culminated by the fact that PPAR $\alpha$ and PPAR $\gamma$ are molecular targets for lipid-lowering fibrate drugs and insulin-sensitizing thiazolidinedione (TZD), respectively [130-132]. Previous studies have also demonstrated that either overexpressing or targeting PPAR $\beta / \delta$ with a synthetic agonist ligand markedly improves exercise endurance, at least in rodents [133-136], indicating that harnessing this NR might be useful for the development of therapeutic strategies against metabolic diseases.

Transcription factor EB (TFEB) has been considered as a master regulator for lysosome biogenesis and autophagy and plays a key role in starvation-induced lipid metabolism such as FAO. In this context, PPAR $\alpha$ is an important mediator of transcriptional outcomes governed by the TFEB-PGC-1 $\alpha$ axis [137-142]. The compelling evidence that PPAR $\alpha$ regulates autophagy has been reported by the Moore laboratory. They have shown that hepatic autophagy is coordinated by two nutrient-sensing NRs, a fasting-activated receptor PPAR $\alpha$ and a nuclear bile acid receptor FXR $[113,114]$. PPAR $\alpha$ is required for fasting-induced autophagy, and its pharmacological activation is sufficient for inducing autophagy, even in a fed state of mouse liver. PPAR $\alpha$ activation increases hepatic autophagy via a direct induction of core autophagy-related genes. Moreover, it also leads to lipophagy [143-145]. A comprehensive cistromic analysis has revealed that a significant number of core autophagyrelated genes are direct PPAR $\alpha$ target genes in mouse liver. Overall, similar to TR $\beta$, PPAR $\alpha$ plays an important role not only in FAO and ketogenesis to provide ATPs and ketone 
bodies, but also in lipophagy to supply free fatty acids as substrates for FAO in a fasted liver $[46,146,147]$. The Kemper laboratory has also demonstrated that cAMP response element binding protein (CREB), a fasting-activated transcription factor, increases expressions of core-autophagy-related genes by binding to their promoter regions [112]. These results indicate that PPAR $\alpha$ cooperates with CREB to control hepatic autophagy at the transcriptional levels. It would be very interesting to investigate the molecular mechanisms by which PPAR $\alpha$ activation leads to lipophagy in liver.

PPAR $\alpha$ activation with $W y-14,643$ has been reported to suppress inflammation in mouse and human models of acute liver injury. This effect seems to be dependent on autophagy activity and $A t g 7$ gene. In particular, autophagy induction in macrophages in response to $\mathrm{Wy}-14,643$ contributes to the protective effects on a lipopolysaccharide (LPS)-induced proinflammatory response [148]. Similarly, a mouse model of acute liver injury showed a reduced autophagy activity and downregulated Ppar $\alpha$ gene expression. These effects can be reversed by inhibiting glycogen synthase kinase $3 \beta$ (GSK3 $\beta$ ) activity, suggesting that a GSK3 $\beta$-PPAR $\alpha$ axis in the liver is important not only for the induction of autophagy but also for subsequent hepatic protection in acute liver injury [149]. Consistently, PPAR $\alpha$ activation reduces the anti-autophagic effects of miR-19a mimic and elevates LC3-II/LC3-I ratio and Beclin-1 expression in models of acute liver injury [150]. Fibroblast growth factor 21 ( Fgf21), a direct PPAR $\alpha$ target gene in the liver, has pleotropic effects on diverse fasting-activated metabolic pathways including gluconeogenesis, FAO, and ketogenesis [151-153]. Fenofibrate, a hypolipidemic drug improves acetaminophen (APAP)-induced liver injury in wild-type mice but not $F g f 21$ knockout mice, indicating that the beneficial effects of fenofibrate are at least in part dependent on Fgf21. In this context, fenofibrate increases LC3-II but decreases p62, resulting in the induction of hepatic autophagy. This mechanism seems to alleviate hepatotoxicity in APAP-treated wild-type mice [154]. Fasting-inducible FGF21 phosphorylates the Thr-1044 residue of the jumonji domain containing 3 (JMJD3/KDM6B) histone lysine demethylase via the activation of protein kinase A (PKA). Phosphorylated JMJD3 is then translocated into the nucleus where it interacts with PPAR $\alpha$, stimulating demethylation of the histone H3K27-me3. This event upregulates global autophagy-network genes including Tfeb, Atg7, Atgl, and Fgf21. This study has also suggested that upregulation of autophagy-related genes by PPAR $\alpha$ depends on JMJD3 histone demethylase [155]. Zinc $\left(\mathrm{Zn}^{2+}\right)$ has been known to stimulate hepatic lipid oxidation via upregulation of lipophagy. $\mathrm{Zn}^{2+}$ increases Ppard expression by promoting metal response element-binding transcription factor (MTF-1) to bind at Ppar $\alpha$ promoter region. This in turn induces expression of key genes involved in autophagy and lipolysis [156]. Autophagy induction is important for the activation of hepatic c stellate cells (HSCs), which lead to liver fibrosis [157]. It has been shown that taurin supplementations reduces arsenic trioxide $\left(\mathrm{As}_{2} \mathrm{O}_{3}\right)$-induced HSCs activation via the inhibition of PPAR $\alpha$ mediated autophagy pathway [158]. Interestingly, autophagy also affects PPAR $\alpha$ activity at the transcriptional levels. It has been reported that hepatic autophagy activity is essential for the functions of $\operatorname{PPAR} \alpha$, particularly in a fasted liver. Liver-specific knockout mice for key autophagy genes Atg5, Atg7, or Vps34 showed a compromised FAO and ketogenesis during a fasting period. These livers of knockout mice revealed marked accumulations of NCoR corepressor that inhibits PPAR $\alpha$-dependent transcription programs such as FAO and ketogenesis $[113,159,160]$.

Cannabinoid-mediated antiproliferative effects in HCC cells have been found to be dependent on the induction of PPAR $\gamma$. Knockdown experiments using siRNAs against PPAR $\gamma$ showed accumulated autophagy markers p62 and LC3B-II, indicating that PPAR $\gamma$ seems to be necessary for autophagy flux in cannabinoid-treated HCC cells [161]. Treatment of pioglitazone, a synthetic PPAR $\gamma$ agonist, ameliorated hepatic steatosis in high-fat diet (HFD) fed mice. In this experiment, it has been proposed that pioglitazone can increase hepatic autophagy along with increased cytosolic lipolysis and FAO probably by upregulating autophagy genes encoding ATG7, LC3, and LAL [162]. 
PPAR $\gamma$ has also been reported to alleviate arsenic $\mathrm{As}_{2} \mathrm{O}_{3}$-induced hepatotoxicity of rat offspring by suppressing ROS-mediated autophagy induction [163]. PPAR $\beta / \delta$ also seems to increase hepatic autophagy. PPAR $\beta / \delta$ activation reduced hepatic steatosis by the induction of autophagy-mediated FAO. Although detailed molecular mechanisms remain to be elucidated, synthetic agonists of PPAR $\beta / \delta$ can enhance AMPK activity that leads to inactivation of mTOR complex. This may trigger lipophagy, providing free fatty acids for mitochondria [164].

\subsection{Liver $X$ Receptor $(L X R \alpha \mathcal{E} L X R \beta)$}

LXRs play a pivotal role in cholesterol metabolism and inflammation. There are two isoforms, $\mathrm{LXR} \alpha$ and $\beta$. LXR $\alpha$ is more abundant in liver and intestine but $\mathrm{LXR} \beta$ is ubiquitously expressed. LXRs have oxidized cholesterol derivatives as physiological ligands [165,166]. Usually, LXR forms a heterodimer complex with RXR, and its more dynamic transactivation occurs upon the treatment of agonist ligands [63]. Global or hepatic knockout mice of LXR $\alpha$ fed with high cholesterol diets result in remarkable cholesterol accumulations in the liver $[167,168]$. Pharmacological LXR activation also markedly increases lipogenesis and fatty livers $[169,170]$. LXR $\alpha$ activation also influences mitochondrial functions by downregulating autophagy-related gene including $A \operatorname{tg} 4 b$ and Rab8B. It turns out that LXR $\alpha$ directly upregulates microRNAs let-7a and miR-34a that decrease stability of ATG4B and Rab8B mRNAs leading to autophagy inhibition in liver [171]. However, non-canonical activation of $\mathrm{LXR} \beta$ in response to dendrogenin A (DDA) appears to have anticancer and chemopreventive effects on a cancer mouse model by inducing lethal autophagy. DDA-mediated LXR $\beta$ activation stimulates expression of autophagy genes such as Lc3 and Tfeb, which are not observed by canonical LXR agonists. This may lead to new perspectives for cancer treatment [172].

\subsection{Pregnane X Receptor (PXR) and Constitutive Androstane Receptor (CAR)}

PXR is an essential NR for the defense mechanism against various foreign compounds called xenobiotics. PXR is activated by a variety of lipophilic xenobiotic molecules such as steroid derivatives, pesticides, herbs, prescribed drugs, endocrine disruptors, and other environmental toxic contaminants $[173,174]$. By sensing these xenobiotic chemicals and endobiotic molecules, PXR modulates expression of drug-metabolizing enzymes and transporters for detoxification in the liver and intestine. As with some of the other adopted orphan receptors, PXR also forms a heterodimer with RXR, which binds to PXR response elements (PXRE) such as a direct repeat 4 (DR4) or DR5 in the regulatory regions of target genes [175]. Mouse chromatin immunoprecipitation-sequencing (ChIP-seq) studies have revealed that PXR activation upregulates genes involved in cell proliferation and drug metabolism, but downregulates genes associated with amino acid and glucose metabolism [176].

PXR has also been shown to regulate hepatic autophagy. PXR positive cells showed upregulated p62/SQSTM1 but downregulated LC3-II, indicative of autophagy suppression. However, these were reversed in Pxr null cells. Pharmacological activation of PXR with rifampicin showed similar effects as shown in PXR positive cells. Mechanistically, p53-mediated induction of $A m p k \beta 1$ gene can be inhibited by its physical interaction with PXR, thereby inhibiting ammonia-inducible hepatic autophagy [177]. Similarly, 18 $\beta$ glycyrrhetinic acid (GA) as a promising hepatoprotective agent significantly decreased apoptosis and autophagic flux in the liver. GA has been shown to activate PXR, which suppresses an AP-lysosome fusion process and lysosomal stability [178]. Overall, PXR activation leads to autophagy suppression in the liver.

CAR is also intimately associated with drug metabolism and detoxification [179]. CAR mainly expressed in the liver plays an important role in energy metabolism [180,181]. CAR activation with a synthetic agonist TCPOBOP could form a heterodimer with RXR, and this complex typically binds to the phenobarbital-responsive enhancer module (PBREM) sequences for the upregulation of xenobiotic enzymes including cytochrome P450 CYP2Bs. 
Current studies regarding the role of CAR in autophagy have not been extensively explored. However, one study has shown that CAR activation by cadmium (Cd), a harmful heavy metal ion and a pollutant in rabbits, induces several Cyp450 genes, resulting in ROS production. Increased ROS levels seem to activate excessive mitophagy and then cause liver damage [182]. Although little is known about CAR-mediated autophagy regulation, it should be an interesting research area to be explored in the future.

\subsection{Hepatocyte Nuclear Factor 4 (HNF4 $\alpha$ \& HNF4 $\gamma$ )}

$\mathrm{HNF} 4 \alpha$ is known to be involved in hepatocyte differentiation and lipid metabolism $[183,184]$ Fatty acids and acyl-CoA thioesters have been proposed to act as endogenous ligands for $\mathrm{HNF} 4 \alpha[185,186]$. HNF4 $\alpha$ activation regulates expression of a broad range of genes related to glucose, lipid, and inflammation via the formation of homodimer or heterodimer with an isoform HNF4 $\gamma$. In addition, HNF4 $\alpha$ can interact with other NRs to modulate hepatic glycolysis, lipid metabolism, and cholesterol homeostasis [187-189]. HNF4 $\alpha$ has been shown to be upregulated in nonalcoholic fatty liver disease (NAFLD). Liver-specific $H n f 4 \alpha$ knockout mice also developed fatty liver $[190,191]$. Recent studies have reported that autophagy activity is compromised in NAFLD owing to reduced ULK1 protein levels. In this context, miRNA Mir214-3p has been proposed to decrease the stability of Ulk1 mRNA by a direct binding to its 3'UTR region. In contrast, $\mathrm{HNF} 4 \alpha$ also directly binds to a specific regulatory region $(-1643 /-1534)$ of $U l k 1$ gene and significantly upregulates its expression [192]. This study suggests that enhancement of Ulk1 expression by either activating HNF4 $\alpha$ or downregulating miRNA Mir214-3p probably alleviates fatty liver disease via the induction of autophagy activity.

\section{6. $R E V-E R B \alpha$ and $R E V-E R B \beta$}

REV-ERBs play key roles in the negative feedback loop of the circadian transcriptional circuits in mammals. Hepatic REV-ERBs synchronize whole-body metabolism with food supplementations and environmental zeitgeber stimuli $[193,194]$. REV-ERBs have two isoforms REV-ERB $\alpha$ and REV-ERB $\beta$ expressed in various tissues including the brain and liver $[180,195,196]$. Heme has been proposed as an endogenous ligand of REV-ERBs and enhances their transrepression functions $[197,198]$. Unlike many other NRs, REV-ERBs act as a constitutive transrepressor of target gene expression by recruiting corepressors NCoR, SMRT, and HDCA3 [193,194]. Previous studies have also revealed that there is a direct competition between REV-ERBs and RORs to bind the same response elements of circadian genes $[199,200]$.

It seems likely that there is a crosstalk between circadian rhythm and autophagy activity. Circadian rhythm has been shown to regulate autophagy via REV-ERB $\alpha$. The number of APs and ALs are daily rhythms in zebrafish liver. In accordance with this, autophagy-related genes are significantly upregulated in the Rev-erb $\alpha$ mutant fish. Among them, Ulk1 turns out to be a direct REV-ERB $\alpha$ target gene. Fasting also alters the expression of clock genes and autophagy-related genes in other peripheral organs [201]. Intriguingly, autophagy also affects circadian rhythms in the liver. Circadian proteins BMAL1, CLOCK, REV-ERB $\alpha$, and CRY1 are targeted to lysosomes for their degradation. In particular, CRY1 proteins contain two LC3-inteacting region motifs (LIR) that facilitate their macroautophagy-mediated degradation. Since CRY1 acts as a negative transcription factor of gluconeogenesis, autophagy-mediated CRY1 degradation may contribute to the maintenance of blood glucose levels during fasting [202].

\subsection{Retinoic Acid Receptor-Related Orphan Receptors ( $R O R \alpha, R O R \beta, \mathcal{E} R O R \gamma)$}

RORs have three major isoforms, $\operatorname{ROR} \alpha, \operatorname{ROR} \beta$, and $\operatorname{ROR} \gamma$. Among them, $\mathrm{ROR} \gamma$ and $\mathrm{ROR} \gamma$ are particularly important for coordinating the circadian rhythm, which affects lipid metabolism and inflammation in the liver [203]. Unlike REV-ERBs, RORs in general function as transcriptional activators. As mentioned above, RORs share DNA binding motifs of circadian clock genes, including Bmal1, with REV-ERBs. Because of this, ROR $\alpha$ 
displays opposite circadian expression patterns of target genes compared with those of REV-ERBs [204]. Although many studies have been done to understand roles of RORs in circadian rhythm and metabolism, little is known that RORs regulate hepatic autophagy. A recent study has reported that $\mathrm{ROR} \alpha$ might be involved in autophagy regulation by controlling the acidity of lysosomes. ROR $\alpha$-deficient mice showed defects of autophagy flux in the liver. These defects in ROR $\alpha$ deficient livers seem to be due to low expression levels of Atp6v1g1 gene encoding a component of the peripheral stalk of v-ATPase [205]. Because v-ATPase controls lysosomal $\mathrm{pH}$, downregulated Atp6v1g1 expression by hepatic ROR $\alpha$ deletion results in autophagy impairments. This suggests that ROR $\alpha$ might oversee lysosomal acidification and an autophagy flux at the transcription level.

\subsection{Estrogen-Related Receptor ( $E R R \alpha, E R R \beta, \mathcal{E} E R R \gamma$ )}

ERRs are orphan NRs that contribute to a variety of cellular metabolism to maintain energy homeostasis. There are three isoforms, $E R R \alpha, E R R \beta$, and ERR $\gamma$. Their hepatic functions have been studied in various conditions such as alcohol and lipid metabolism, bile acid synthesis, gluconeogenesis, and iron metabolism [206-208]. Until now, its endogenous ligand has not been identified. Among three ERR isoforms, ERR $\alpha$ is ubiquitously expressed and is required for both mitochondrial biogenesis and FAO [209,210]. ERRs are able to bind to ERR response element (ERRE) as a monomer or dimer of two ERRs [210]. ERR $\alpha$ enhances its transactivation activity by recruiting potent coactivators such as PGC- $1 \alpha / \beta$ [80]. In terms of autophagy regulation, ERR $\alpha$ has been shown to be induced by AMPK or SIRT1 activation, which facilitates autophagosome formation. ERR $\alpha$ also increases expression of Atg genes containing ERREs in macrophages [211]. As described earlier, ERR $\alpha$ cooperates with TR $\beta 1$ to regulate many genes involved in mitochondrial metabolic pathway. ERR $\alpha$ seems to be required for T3-mediated mitochondrial biogenesis, fission, and mitophagy. For example, increased Ulk1 expression by T3 is mediated by ERR $\alpha$ and activated ULK1 in turn promotes interactions between a docking receptor FUNDC1 and LC3B-II to induce mitophagy. Taken together, the TR-ERR $\alpha$ axis leads to a mitochondrial clearance via a ULK1-FUNDC1 pathway [72].

\subsection{Small Heterodimer Partner (SHP)}

SHP is an atypical orphan NR due to its absence of DNA-binding domain and is predominantly expressed in the liver and intestine, where it plays an essential role in bile acid biosynthesis [212-214]. Although synthetic chemical ligands have been developed, any endogenous ligand has not been reported yet [215]. Because of its unique structure, SHP cannot bind to DNA directly. Therefore, SHP functions as a corepressor and interacts with other NRs to control target gene expression. Three modes of action mechanisms have been proposed. First, SHP inhibits coactivator recruitment to DNA-binding transcription factors via a direct interaction. Second, SHP recruits more corepressor proteins. Lastly, SHP inhibits DNA binding of other transcription factors [215]. Recent studies have found that SHP and FXR cooperates to regulate the expression of autophagy-related genes such as Atg7 and Atg12 to restore autophagic flux in the liver [115]. SHP-mediated epigenetic regulation of hepatic autophagy has also been reported [216]. Hepatic autophagy is maintained by two-layered transcriptional programs via a sequential action of two NRs FXR and SHP. FXR first suppresses hepatic autophagy, which is then sustained by SHP in a fed state. To do this, SHP represses the expression of autophagy-related genes by recruiting histone demethylase LSD1, a repressive histone modifying enzyme in response to FGF19 [216]. In a fed or FGF19 treated condition, hepatic SHP recruits LSD1 and then disrupts CREBCRTC2 complexes, resulting in reduced expression of CREB-target autophagy related genes such as Tfeb, Atg3, Atg7, and Atg10. This downregulation of autophagy genes seems to suppress hepatic autophagy. In HSCs, autophagy activation is necessary for the induction of profibrogenic gene expression. Consistent with its role in hepatocytes, SHP also inhibits autophagy in HSCs, which may be beneficial for the prevention of liver fibrosis. Shp knockdown experiments showed increased expression of fibrotic-related genes such as 
$\alpha-S M A$, collagen I, and TIMP1 [217]. Because of autophagy suppression by SHP in HSCs, further investigation should be helpful for understanding the role of SHP in liver fibrosis. The studies of adopted and orphan nuclear receptors for hepatic autophagy regulation are summarized in Table 2.

Table 2. Adopted \& orphan nuclear receptors coordinate hepatic autophagy.

\begin{tabular}{|c|c|c|c|c|c|}
\hline NRs & $\begin{array}{l}\text { Ligand/ } \\
\text { Activator }\end{array}$ & Study Model & Autophagy & Mechanism of Action & Refs. \\
\hline \multirow{7}{*}{ FXR } & \multirow[b]{2}{*}{ GW4064 } & Mouse liver/ileum & $\downarrow$ & $\begin{array}{l}\text { p62 gene } \uparrow \rightarrow \text { tumorigenesis } \downarrow \& \\
\text { inflammation } \downarrow\end{array}$ & [110] \\
\hline & & Mouse liver & $\downarrow$ & $\begin{array}{c}\text { Autophagy flux } \downarrow \\
\text { Autophagy related genes } \downarrow \\
\text { Competition with PPAR } \alpha \text { for DR1 binding } \\
\text { Disruption of a CREB-CRTC2 complex }\end{array}$ & {$[112,113]$} \\
\hline & Bile acids & $\begin{array}{l}\text { Fxr-l- liver, } \\
\text { primary mouse } \\
\text { hepatocytes }\end{array}$ & $\downarrow$ & $\begin{aligned} \text { Rab7 gene } \downarrow & \rightarrow \text { AP-lysosome fusion } \downarrow \rightarrow \text { p62 } \\
\uparrow & \rightarrow \text { autophagy flux } \downarrow\end{aligned}$ & [111] \\
\hline & - & $\begin{array}{l}\text { FS DKO mice } \\
\text { FS LDKO mice }\end{array}$ & $\uparrow$ & Autophagy-related genes $\uparrow$ & [115] \\
\hline & OCA & \multirow{2}{*}{$\begin{array}{l}\text { Human cholestatic } \\
\text { liver }\end{array}$} & $\downarrow$ & $\begin{aligned} \text { Rubicon gene } \uparrow & \rightarrow \text { AP \& lysosome fusion } \downarrow \\
& \rightarrow \text { AL } \downarrow\end{aligned}$ & \multirow{2}{*}{ [118] } \\
\hline & UDCA & & $\uparrow$ & $\begin{aligned} \text { Rubicon gene } \downarrow & \rightarrow \text { AP \& lysosome fusion } \uparrow \\
& \rightarrow \text { AL } \uparrow\end{aligned}$ & \\
\hline & $\mathrm{EtOH}$ & $F x r^{-/-}$liver & $\downarrow$ & $\begin{array}{c}\text { FoxO3-mediated autophagy-related genes } \downarrow \\
\quad \rightarrow \text { hepatotoxicity } \uparrow \rightarrow \text { steatosis } \uparrow\end{array}$ & [116] \\
\hline \multirow{6}{*}{$\operatorname{PPAR} \alpha$} & $\begin{array}{l}\text { Wy-14,643 } \\
\text { GW7647 }\end{array}$ & $\begin{array}{l}\text { Mouse liver, } \\
\text { AML12 }\end{array}$ & $\uparrow$ & $\begin{array}{l}\text { PPAR } \alpha \text { competes with FXR to bind to DR1 } \\
\text { biding site of autophagy-related genes }\end{array}$ & [113] \\
\hline & Wy-14643 & $\begin{array}{c}\text { Macrophage, } \\
\text { Acute liver injury } \\
\text { (LPS) }\end{array}$ & $\uparrow$ & $\begin{array}{c}\text { PPAR } \alpha \text {-induced autophagy } \uparrow \rightarrow \text { Beclin1 gene } \\
\uparrow \rightarrow \text { LC3-II/I ratio } \uparrow \rightarrow \text { miR-19a gene } \downarrow \rightarrow \\
\text { inflammation } \downarrow \rightarrow \text { acute liver injury } \downarrow\end{array}$ & [150] \\
\hline & Fenofibrate & APAP-liver injury & $\uparrow$ & $\begin{array}{c}\text { Fgf21 gene } \uparrow \rightarrow \text { LC3-II } \rightarrow \text { p62 } \downarrow \rightarrow \\
\text { APAP-liver injury } \downarrow\end{array}$ & [154] \\
\hline & Fasting & Mouse liver & $\uparrow$ & $\begin{array}{c}\text { Fasting } \rightarrow \text { Fgf } 21 \text { gene } \uparrow \rightarrow \text { PKA activation } \uparrow \\
\rightarrow \text { JMJD3 phosphorylation } \uparrow \rightarrow \\
\text { PPAR } \alpha \text {-mediated autophagy-related genes } \uparrow\end{array}$ & [155] \\
\hline & $\mathrm{Zn}^{2+}$ & Yellow catfish liver & $\uparrow$ & $\begin{array}{l}\mathrm{Zn}^{2+} \rightarrow \text { MTF-1-mediated Ppar } \alpha \text { gene } \uparrow \rightarrow \\
\text { autophagy- related genes } \uparrow \rightarrow \text { lipophagy } \uparrow\end{array}$ & [156] \\
\hline & Taurin & $\begin{array}{l}\text { HSC in mouse } \\
\text { liver }\end{array}$ & $\uparrow$ & $\begin{array}{l}\text { PPAR } \alpha \text {-mediated autophagy-related genes } \downarrow \\
\rightarrow \text { arsenic trioxide-induced HSC activation } \downarrow\end{array}$ & [158] \\
\hline $\operatorname{PPAR} \beta / \delta$ & GW501516 & $\begin{array}{l}\text { Obese mouse liver } \\
\text { Aged mouse liver } \\
\text { HepG2, primary } \\
\text { mouse hepatocytes }\end{array}$ & $\uparrow$ & $\begin{array}{c}\text { AMPK } \uparrow \rightarrow \text { mTORC } 1 \downarrow \rightarrow \text { autophagy } \uparrow \rightarrow \\
\text { lipophagy } \uparrow \rightarrow \text { FAO } \uparrow\end{array}$ & [164] \\
\hline \multirow{3}{*}{ PPAR $\gamma$} & Cannabinoid & HepG2 & $\uparrow$ & $\begin{array}{c}\text { eIF2 } \alpha \rightarrow \text { TRIB3 } \rightarrow \text { Ppar } \gamma \text { gene } \uparrow \rightarrow \\
\text { autophagic flux } \uparrow \rightarrow \text { apoptosis } \uparrow \\
\rightarrow \text { HCC } \downarrow \\
\text { AMPK } \uparrow\end{array}$ & [161] \\
\hline & Pioglitazone & $\begin{array}{l}\text { AML12, HFD-fed } \\
\text { mice }\end{array}$ & $\uparrow$ & $\begin{array}{c}\text { PPAR } \gamma \text { activation } \uparrow \rightarrow \text { autophagy related } \\
\text { genes } A \operatorname{tg} 7, L c 3, \& \text { al } \uparrow \rightarrow \text { autophagy } \uparrow \rightarrow \\
\text { lipolysis \& FAO } \uparrow \rightarrow \text { hepatic steatosis } \downarrow\end{array}$ & [162] \\
\hline & $\mathrm{As}_{2} \mathrm{O}_{3}$ & Rat offspring liver & $\uparrow$ & $\begin{array}{c}\text { PPAR } \gamma \rightarrow \text { ROS-mediated autophagy } \uparrow \rightarrow \\
\mathrm{As}_{2} \mathrm{O}_{3} \text { induced hepatotoxicity } \downarrow\end{array}$ & [163] \\
\hline
\end{tabular}


Table 2. Cont.

\begin{tabular}{|c|c|c|c|c|c|}
\hline NRs & $\begin{array}{l}\text { Ligand/ } \\
\text { Activator }\end{array}$ & Study Model & Autophagy & Mechanism of Action & Refs. \\
\hline $\mathrm{LXR} \alpha$ & $\begin{array}{l}\text { GW3965 } \\
\text { TO901317 }\end{array}$ & $\begin{array}{l}\text { Hepatocytes, HFD } \\
\text { mouse liver, } \\
\text { HepG2 }\end{array}$ & $\downarrow$ & $\begin{array}{c}\text { let7a2 \& miR34a genes } \uparrow \rightarrow \text { Atg } 4 B \& \text { Rab8B } \\
\text { genes } \downarrow \rightarrow \text { AP-lysosome fusion } \downarrow \rightarrow \\
\text { lipophagy } \downarrow \rightarrow \text { FAO } \downarrow \rightarrow \text { hepatic steatosis } \uparrow\end{array}$ & [172] \\
\hline $\mathrm{HNF} 4 \alpha$ & - & HFD-fed mice & $\uparrow$ & $\begin{array}{c}\text { HFD } \rightarrow \text { miR214-3p gene } \uparrow \rightarrow \text { HNF4 } \alpha \text {-driven } \\
\quad \text { Ulk1 mRNA } \downarrow \rightarrow \text { autophagy } \downarrow\end{array}$ & [192] \\
\hline $\begin{array}{l}\mathrm{REV}- \\
\mathrm{ERB} \alpha\end{array}$ & - & $\begin{array}{l}\text { Zebrafish liver } \\
\text { Mouse liver }\end{array}$ & $\downarrow$ & $\begin{array}{c}\text { REV-ERB } \alpha \rightarrow \text { Ulk1 gene } \downarrow \\
\text { Autophagy } \rightarrow \text { degradation of circadian } \\
\text { proteins BMAL1, CLOCK, REV-ERB } \alpha \text {, and } \\
\text { CRY1 } \uparrow\end{array}$ & {$[201,202]$} \\
\hline $\mathrm{ROR} \alpha$ & - & Ror $\alpha$ LKO mice & $\uparrow$ & $\begin{array}{c}\text { ROR } \alpha \rightarrow \text { Atp6v1g1 gene } \uparrow \rightarrow \text { lysosomal } \\
\text { acidification } \uparrow \rightarrow \text { autophagy } \uparrow\end{array}$ & [205] \\
\hline $\mathrm{ERR} \alpha$ & - & $\begin{array}{l}\text { Macrophage, } \\
\text { HepG2, mouse } \\
\text { liver }\end{array}$ & $\uparrow$ & $\begin{array}{c}\text { AMPK/SIRT1 activation } \rightarrow \text { Err } \alpha \text { gene } \uparrow \rightarrow \\
\text { Atg5, Becn1, Atg16l1, Lc3b, } \mathcal{E} \text { Ambra1 genes } \\
\rightarrow \text { AP } \uparrow \\
\text { ERR } \alpha \rightarrow \text { Ulk1 gene } \uparrow \rightarrow \text { FUNDC1-LC3B-II } \\
\text { interaction } \uparrow \rightarrow \text { mitophagy } \uparrow\end{array}$ & {$[72,211]$} \\
\hline \multirow[t]{2}{*}{ SHP } & FGF19 & $\begin{array}{l}\text { Mouse liver, } S h^{-/-} \\
\text {mice } \\
L s d 1^{-/-} \text {mice }\end{array}$ & $\downarrow$ & $\begin{array}{c}\text { Feeding or FGF19 } \rightarrow \text { FXR-SHP-LSD1 } \\
\text { interaction } \uparrow \rightarrow \text { disrupting CREB-CRTC2 } \\
\text { complex } \rightarrow \text { autophagy related genes } \downarrow \rightarrow \\
\text { autophagy } \downarrow\end{array}$ & [216] \\
\hline & & HSC & $\downarrow$ & $\begin{array}{c}\text { Shp knockdown } \rightarrow \text { autophagy related genes } \\
\begin{aligned} \uparrow \rightarrow \text { autophagy } \uparrow & \rightarrow \text { fibrotic-related genes } \uparrow \\
& \rightarrow \text { fibrosis } \uparrow\end{aligned}\end{array}$ & [217] \\
\hline
\end{tabular}

E2, Estrogen; AMPK, AMP-activated protein kinase; mTOR, mammalian target of rapamycin; HK2, hexokinase 2; ULK1, unc-51-like kinase 1; FFA, free fatty acid; FAO, fatty acid oxidation; ROS, reactive oxygen species; CaMKK2, calcium/calmodulin dependent protein kinase kinase 2; FUNDC1, Fun14 domain containing 1; DAPK2, death associated protein kinase 2; CRTC2, CREB regulated transcription coactivator 2; Fgf21, fibroblast growth factor 21; MTF-1, metal regulatory transcription factor 1; FS DKO, Fxr/Shp double knockout; FS LDKO, liverspecific Fxr/Shp double knockout; OCA, obeticholic acid; UDCA, ursodeoxycholic acid; EtOH, ethanol; LPS lipopolysaccharide; APAP, acetaminophen; HSC, hepatic stellate cell; eIF2 $\alpha$, eukaryotic translation initiation factor $2 \alpha$; TRIB3, Tribbles pseudokinase 3; HCC, hepatocellular carcinoma; Lal, lipase A, lysosomal acid type; HFD, high-fat diet; $\uparrow$, increase; $\rightarrow$, promote; $\downarrow$, decrease.

\section{Conclusions}

In the last two decades, mounting evidence strongly suggests that hepatic autophagy can be controlled in the nucleus. Although many transcription factors, including NRs, have been identified for autophagy regulation, we still do not fully understand its physiological and pathological significance. Nevertheless, it is very likely that transcriptional control of a significant number of autophagy genes acts in concert with their post-translational regulation to advance the exquisite coordination of autophagic flux, in particular during long-term starvation or chronic stresses. Certainly, major proteins involved in autophagy machinery and cargo receptors themselves undergo autophagy-mediated degradation. In addition to this, lysosomes are also consumed in the process of autolysosome formation. Therefore, the transcriptional upregulation of lysosomal and autophagy-related genes could be a robust compensatory response against depletion of corresponding proteins during autophagy. Intriguingly, nuclear events of autophagy regulation are not limited to the transcriptional levels, but also involve post-transcriptional levels, highlighting complex layers of autophagy regulation (Figure 3). 

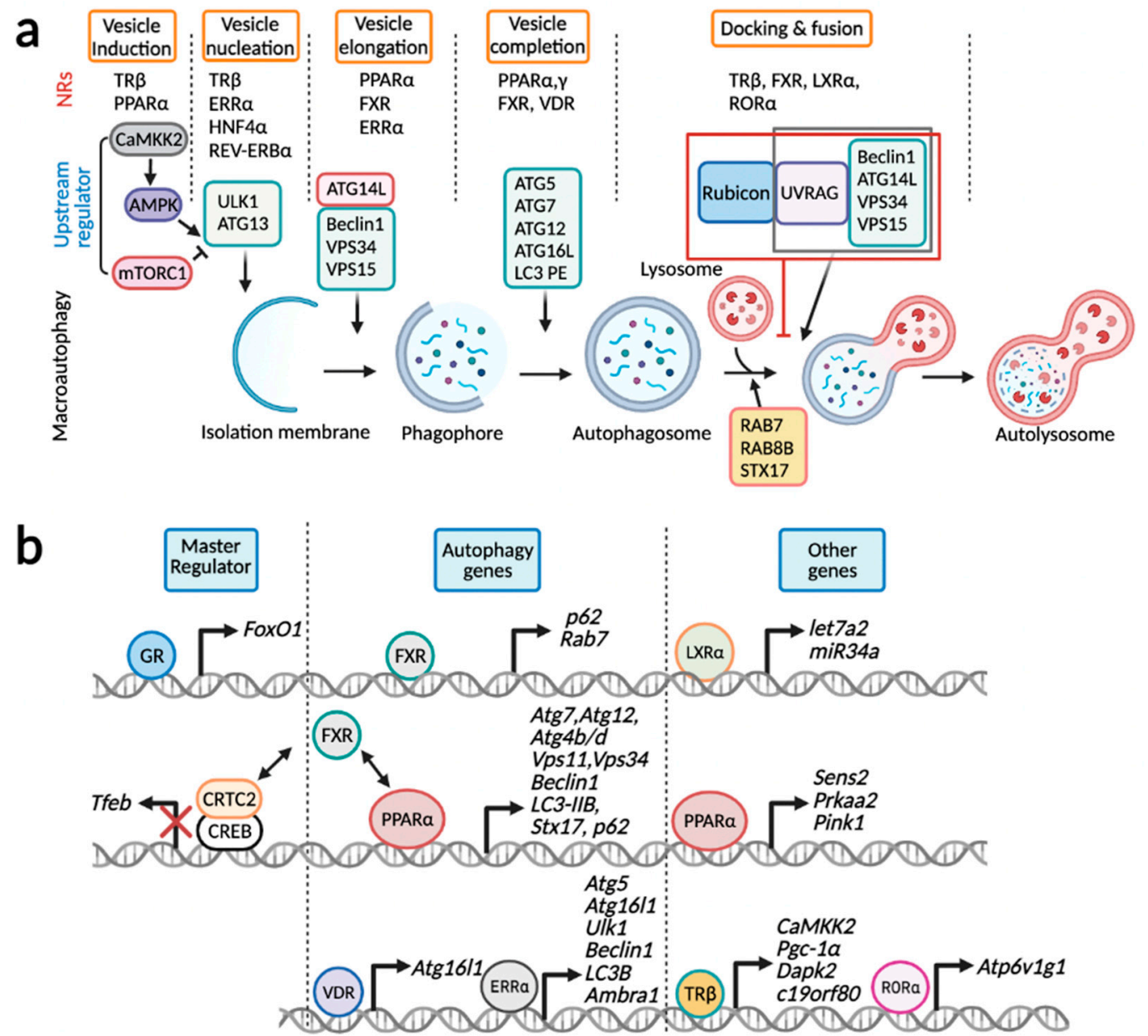

Figure 3. Transcriptional control of hepatic autophagy by nuclear receptors. (a) Each step of macroautophagy is typically controlled by multiple NRs: vesicle induction (TR $\beta$ and PPAR $\alpha$ ), vesicle nucleation $(T R \beta, E R R \alpha, H N F 4 \alpha$, and REV-ERB $\alpha)$, vesicle elongation (PPAR $\alpha, F X R$, and ERR $\alpha$ ), vesicle completion (PPAR $\alpha$, PPAR $\gamma$, FXR, and VDR), and docking and fusion (TR $\beta$, FXR, LXR $\alpha$ and ROR $\alpha$ ). (b) GR and FXR regulate expression of genes encoding master transcription factors FoxO1 and TFEB. $\operatorname{PPAR} \alpha, E R R \alpha, V D R$, and FXR control genes involved in core autophagy-related genes. FXR typically downregulates these core autophagy genes via the disruption of CREB-CRTC2 complex or competition with PPAR $\alpha$. Lastly, $\mathrm{LXR} \alpha$ increases expressions of miRNAs let7a2 and miR34a that in in turn downregulate transcripts of $A \operatorname{tg} 4 b$ and $R a b 8 b$ genes. PPAR $\alpha$ and TR $\beta$ increases expressions of genes associated with either upstream regulators (Sestrin2, AMPK, CaMKK2, DAPK2) or PINK1, a critical kinase for mitophagy. ROR $\alpha$ induces Atp6v1g1 gene encoding a subunit of v-ATPase, which is critical for lysosomal acidification. This schematic diagram was created in BioRender.com (accessed on 5 February 2022).

Each step of macroautophagy is regulated by multiple NRs: TR $\beta$ and PPAR $\alpha$ for vesicle induction, $\mathrm{TR} \beta, \mathrm{ERR} \alpha, \mathrm{HNF} 4 \alpha$, and REV-ERB $\alpha$ for vesicle nucleation, PPAR $\alpha, \mathrm{FXR}$, and ERR $\alpha$ for vesicle elongation, $\operatorname{PPAR} \alpha, \operatorname{PPAR} \gamma, \mathrm{FXR}$, and VDR for vesicle completion, and $\mathrm{TR} \beta, \mathrm{FXR}, \mathrm{LXR} \alpha$, and $\mathrm{ROR} \alpha$ for docking and fusion (Figure 3a). It is of interest to note that $\operatorname{PPAR} \alpha, \operatorname{FXR}, \operatorname{ERR} \alpha$, and $\operatorname{TR} \beta$ engage in multiple steps of macroautophagy by regulating expression of key genes encoding upstream regulators, and autophagy machinery proteins for vesicle nucleation, elongation, completion, and docking and fusion. By contrast, it seems likely that a certain NR regulates specific sets of genes involved in the distinct step of macroautophagy. GR and FXR regulate expression of genes encoding FoxO1 and TFEB, master transcription factors for autophagy gene regulation (Figure 3b). Intriguingly, in addition to the inductions of genes $p 62$ and Rab7, FXR dynamically suppresses 
a variety of autophagy-related genes via either the disruption of CREB-CRTC2 complex or a direct genomic competition with PPAR $\alpha$ for binding to DR1 sites. Expressions of core autophagy-related genes are primarily increased by $\operatorname{PPAR} \alpha, \operatorname{ERR} \alpha$, and VDR. Genes encoding upstream regulators were also controlled by PPAR $\alpha$ and TR $\beta$. LXR $\alpha$ indirectly downregulates Atg $4 b$ and Rab8b transcripts by the inductions of miRNAs let7a2 and miR34a. Lastly, $\operatorname{ROR} \alpha$ also indirectly promotes macroautophagy by increasing lysosomal acidification through the upregulation of Atp6v1g1 gene encoding a subunit of v-ATPase. Overall, NRs directly and indirectly control transcription or transcripts of autophagy-related genes via various mechanisms including transactivation, transrepression, recruitments of chromatin remodeling proteins, and miRNAs.

NRs have been attractive molecular targets to treat liver diseases because of their tight connections to the regulation of various metabolic pathways. Thus, in addition to affecting diverse aspects of liver biology, targeting hepatic NRs has been shown to actively control autophagy in various cell types such as hepatocytes, HSCs, Kupffer cells, and hepatoma cell lines. These modulations of autophagy activity in a cell-type specific manner can be very useful for developing novel therapeutics with less side effects. Moreover, it would be of importance to discover novel NR target genes encoding key proteins, miRNAs, and long non-coding RNAs (lncRNAs), which can affect post-translational modifications of core autophagy machinery proteins or become cargo receptors themselves to modulate selective autophagy. For the next decade, it will be a very exciting period to understand whether diverse NRs also regulate a specific type of selective autophagy in a cell type-specific manner in the liver, and if these regulatory mechanisms can be harnessed to fight metabolic liver diseases.

Author Contributions: Conceptualization, E.Y.K. and J.M.L.; writing-original draft preparation, E.Y.K.; writing-review and editing, J.M.L.; visualization, E.Y.K.; supervision, J.M.L.; funding acquisition, E.Y.K. All authors have read and agreed to the published version of the manuscript.

Funding: This research was supported by Kyungpook National University Development Project Research Fund, 2020 to E.Y.K.

Institutional Review Board Statement: Not applicable.

Informed Consent Statement: Not applicable.

Data Availability Statement: Not applicable.

Acknowledgments: We are indebted to current and past members of the Nuclear Receptor and Disease Laboratory for discussions. We apologize to colleagues whose work and publications could not be cited due to space constrains.

Conflicts of Interest: The authors declare no conflict of interest.

\section{References}

1. Kaur, J.; Debnath, J. Autophagy at the crossroads of catabolism and anabolism. Nat. Rev. Mol. Cell Biol. 2015, 16, 461-472. [CrossRef] [PubMed]

2. Mizushima, N.; Komatsu, M. Autophagy: Renovation of cells and tissues. Cell 2011, 147, 728-741. [CrossRef] [PubMed]

3. Mizushima, N.; Levine, B.; Cuervo, A.M.; Klionsky, D.J. Autophagy fights disease through cellular self-digestion. Nature 2008, 451, 1069-1075. [CrossRef] [PubMed]

4. Dou, Z.; Xu, C.; Donahue, G.; Shimi, T.; Pan, J.A.; Zhu, J.; Ivanov, A.; Capell, B.C.; Drake, A.M.; Shah, P.P.; et al. Autophagy mediates degradation of nuclear lamina. Nature 2015, 527, 105-109. [CrossRef] [PubMed]

5. Mochida, K.; Oikawa, Y.; Kimura, Y.; Kirisako, H.; Hirano, H.; Ohsumi, Y.; Nakatogawa, H. Receptor-mediated selective autophagy degrades the endoplasmic reticulum and the nucleus. Nature 2015, 522, 359-362. [CrossRef] [PubMed]

6. He, C.; Klionsky, D.J. Regulation mechanisms and signaling pathways of autophagy. Annu. Rev. Genet. 2009, 43, 67-93. [CrossRef]

7. Li, W.W.; Li, J.; Bao, J.K. Microautophagy: Lesser-known self-eating. Cell Mol. Life Sci. 2012, 69, 1125-1136. [CrossRef]

8. Ahlberg, J.; Marzella, L.; Glaumann, H. Uptake and degradation of proteins by isolated rat liver lysosomes. Suggestion of a microautophagic pathway of proteolysis. Lab. Investig. 1982, 47, 523-532.

9. Mijaljica, D.; Prescott, M.; Devenish, R.J. Microautophagy in mammalian cells: Revisiting a 40-year-old conundrum. Autophagy 2011, 7, 673-682. [CrossRef] 
10. Kaushik, S.; Cuervo, A.M. The coming of age of chaperone-mediated autophagy. Nat. Rev. Mol. Cell Biol. 2018, 19, 365-381. [CrossRef]

11. Kaushik, S.; Cuervo, A.M. Chaperone-mediated autophagy: A unique way to enter the lysosome world. Trends Cell Biol. 2012, 22, 407-417. [CrossRef]

12. Wagner, M.; Zollner, G.; Trauner, M. Nuclear receptors in liver disease. Hepatology 2011, 53, 1023-1034. [CrossRef] [PubMed]

13. Shulman, A.I.; Mangelsdorf, D.J. Retinoid x receptor heterodimers in the metabolic syndrome. N. Engl. J. Med. 2005, 353, 604-615. [CrossRef] [PubMed]

14. Sonoda, J.; Pei, L.; Evans, R.M. Nuclear receptors: Decoding metabolic disease. FEBS Lett. 2008, 582, 2-9. [CrossRef] [PubMed]

15. Sayaf, K.; Zanotto, I.; Russo, F.P.; Gabbia, D.; De Martin, S. The Nuclear Receptor PXR in Chronic Liver Disease. Cells 2021, 11, 61. [CrossRef] [PubMed]

16. Xue, R.; Su, L.; Lai, S.; Wang, Y.; Zhao, D.; Fan, J.; Chen, W.; Hylemon, P.B.; Zhou, H. Bile Acid Receptors and the Gut-Liver Axis in Nonalcoholic Fatty Liver Disease. Cells 2021, 10, 2806. [CrossRef]

17. Petrescu, A.D.; DeMorrow, S. Farnesoid X Receptor as Target for Therapies to Treat Cholestasis-Induced Liver Injury. Cells 2021, 10, 1846. [CrossRef]

18. Fougerat, A.; Montagner, A.; Loiseau, N.; Guillou, H.; Wahli, W. Peroxisome Proliferator-Activated Receptors and Their Novel Ligands as Candidates for the Treatment of Non-Alcoholic Fatty Liver Disease. Cells 2020, 9, 1638. [CrossRef]

19. Sandoval, H.; Thiagarajan, P.; Dasgupta, S.K.; Schumacher, A.; Prchal, J.T.; Chen, M.; Wang, J. Essential role for Nix in autophagic maturation of erythroid cells. Nature 2008, 454, 232-235. [CrossRef]

20. Morselli, E.; Marino, G.; Bennetzen, M.V.; Eisenberg, T.; Megalou, E.; Schroeder, S.; Cabrera, S.; Benit, P.; Rustin, P.; Criollo, A.; et al. Spermidine and resveratrol induce autophagy by distinct pathways converging on the acetylproteome. J. Cell Biol. 2011, 192, 615-629. [CrossRef]

21. Rabinowitz, J.D.; White, E. Autophagy and metabolism. Science 2010, 330, 1344-1348. [CrossRef]

22. Silwal, P.; Paik, S.; Jeon, S.M.; Jo, E.K. Nuclear Receptors as Autophagy-Based Antimicrobial Therapeutics. Cells 2020, 9 , 1979. [CrossRef] [PubMed]

23. Mizushima, N.; Yoshimori, T.; Levine, B. Methods in mammalian autophagy research. Cell 2010, 140, 313-326. [CrossRef] [PubMed]

24. Reggiori, F. Membrane origin for autophagy. Curr. Top. Dev. Biol. 2006, 74, 1-30. [CrossRef]

25. Lamb, C.A.; Yoshimori, T.; Tooze, S.A. The autophagosome: Origins unknown, biogenesis complex. Nat. Rev. Mol. Cell Biol. 2013, 14, 759-774. [CrossRef] [PubMed]

26. Matsunaga, K.; Noda, T.; Yoshimori, T. Binding Rubicon to cross the Rubicon. Autophagy 2009, 5, 876-877. [CrossRef]

27. Matsunaga, K.; Saitoh, T.; Tabata, K.; Omori, H.; Satoh, T.; Kurotori, N.; Maejima, I.; Shirahama-Noda, K.; Ichimura, T.; Isobe, T.; et al. Two Beclin 1-binding proteins, Atg14L and Rubicon, reciprocally regulate autophagy at different stages. Nat. Cell Biol. 2009, 11, 385-396. [CrossRef]

28. Gordon, P.B.; Seglen, P.O. Prelysosomal convergence of autophagic and endocytic pathways. Biochem. Biophys. Res. Commun. 1988, 151, 40-47. [CrossRef]

29. Galluzzi, L.; Pietrocola, F.; Levine, B.; Kroemer, G. Metabolic control of autophagy. Cell 2014, 159, 1263-1276. [CrossRef]

30. Chun, Y.; Kim, J. Autophagy: An Essential Degradation Program for Cellular Homeostasis and Life. Cells 2018, 7, 278. [CrossRef]

31. Marino, G.; Niso-Santano, M.; Baehrecke, E.H.; Kroemer, G. Self-consumption: The interplay of autophagy and apoptosis. Nat. Rev. Mol. Cell Biol. 2014, 15, 81-94. [CrossRef] [PubMed]

32. Maiuri, M.C.; Zalckvar, E.; Kimchi, A.; Kroemer, G. Self-eating and self-killing: Crosstalk between autophagy and apoptosis. Nat. Rev. Mol. Cell Biol. 2007, 8, 741-752. [CrossRef] [PubMed]

33. Moulis, M.; Vindis, C. Autophagy in Metabolic Age-Related Human Diseases. Cells 2018, 7, 149. [CrossRef] [PubMed]

34. Weiskirchen, R.; Tacke, F. Relevance of Autophagy in Parenchymal and Non-Parenchymal Liver Cells for Health and Disease Cells 2019, 8, 16. [CrossRef]

35. Yazdani, H.O.; Huang, H.; Tsung, A. Autophagy: Dual Response in the Development of Hepatocellular Carcinoma. Cells 2019, 8, 91. [CrossRef]

36. Klionsky, D.J.; Petroni, G.; Amaravadi, R.K.; Baehrecke, E.H.; Ballabio, A.; Boya, P.; Bravo-San Pedro, J.M.; Cadwell, K.; Cecconi, F.; Choi, A.M.K.; et al. Autophagy in major human diseases. EMBO J. 2021, 40, e108863. [CrossRef]

37. Jin, M.; Liu, X.; Klionsky, D.J. SnapShot: Selective autophagy. Cell 2013, 152, 368-368.e2. [CrossRef]

38. Stolz, A.; Ernst, A.; Dikic, I. Cargo recognition and trafficking in selective autophagy. Nat. Cell Biol. 2014, 16, 495-501. [CrossRef]

39. Kirisako, T.; Baba, M.; Ishihara, N.; Miyazawa, K.; Ohsumi, M.; Yoshimori, T.; Noda, T.; Ohsumi, Y. Formation process of autophagosome is traced with Apg8/Aut7p in yeast. J. Cell Biol. 1999, 147, 435-446. [CrossRef]

40. Fullgrabe, J.; Klionsky, D.J.; Joseph, B. The return of the nucleus: Transcriptional and epigenetic control of autophagy. Nat. Rev. Mol. Cell Biol. 2014, 15, 65-74. [CrossRef]

41. Fullgrabe, J.; Ghislat, G.; Cho, D.H.; Rubinsztein, D.C. Transcriptional regulation of mammalian autophagy at a glance. J. Cell Sci. 2016, 129, 3059-3066. [CrossRef] [PubMed]

42. Di Malta, C.; Cinque, L.; Settembre, C. Transcriptional Regulation of Autophagy: Mechanisms and Diseases. Front. Cell Dev. Biol. 2019, 7, 114. [CrossRef] [PubMed] 
43. Baek, S.H.; Kim, K.I. Epigenetic Control of Autophagy: Nuclear Events Gain More Attention. Mol. Cell 2017, 65, 781-785. [CrossRef] [PubMed]

44. Chawla, A.; Repa, J.J.; Evans, R.M.; Mangelsdorf, D.J. Nuclear receptors and lipid physiology: Opening the X-files. Science 2001, 294, 1866-1870. [CrossRef]

45. Evans, R.M.; Mangelsdorf, D.J. Nuclear Receptors, RXR, and the Big Bang. Cell 2014, 157, 255-266. [CrossRef]

46. Evans, R.M.; Barish, G.D.; Wang, Y.X. PPARs and the complex journey to obesity. Nat. Med. 2004, 10, 355-361. [CrossRef]

47. Sheppard, K.A.; Phelps, K.M.; Williams, A.J.; Thanos, D.; Glass, C.K.; Rosenfeld, M.G.; Gerritsen, M.E.; Collins, T. Nuclear integration of glucocorticoid receptor and nuclear factor-kappaB signaling by CREB-binding protein and steroid receptor coactivator-1. J. Biol. Chem. 1998, 273, 29291-29294. [CrossRef]

48. Surjit, M.; Ganti, K.P.; Mukherji, A.; Ye, T.; Hua, G.; Metzger, D.; Li, M.; Chambon, P. Widespread negative response elements mediate direct repression by agonist-liganded glucocorticoid receptor. Cell 2011, 145, 224-241. [CrossRef]

49. Knutti, D.; Kaul, A.; Kralli, A. A tissue-specific coactivator of steroid receptors, identified in a functional genetic screen. Mol. Cell Biol. 2000, 20, 2411-2422. [CrossRef]

50. Goldstein, I.; Baek, S.; Presman, D.M.; Paakinaho, V.; Swinstead, E.E.; Hager, G.L. Transcription factor assisted loading and enhancer dynamics dictate the hepatic fasting response. Genome Res. 2017, 27, 427-439. [CrossRef]

51. Zhang, D.; Liu, K.; Hu, W.; Lu, X.; Li, L.; Zhang, Q.; Huang, H.; Wang, H. Prenatal dexamethasone exposure caused fetal rats liver dysplasia by inhibiting autophagy-mediated cell proliferation. Toxicology 2021, 449, 152664. [CrossRef] [PubMed]

52. Osborne, C.K.; Schiff, R. Estrogen-receptor biology: Continuing progress and therapeutic implications. J. Clin. Oncol. 2005, 23, 1616-1622. [CrossRef] [PubMed]

53. Li, Z.; Tuteja, G.; Schug, J.; Kaestner, K.H. Foxa1 and Foxa2 are essential for sexual dimorphism in liver cancer. Cell 2012, 148, 72-83. [CrossRef] [PubMed]

54. Lupien, M.; Eeckhoute, J.; Meyer, C.A.; Wang, Q.; Zhang, Y.; Li, W.; Carroll, J.S.; Liu, X.S.; Brown, M. FoxA1 translates epigenetic signatures into enhancer-driven lineage-specific transcription. Cell 2008, 132, 958-970. [CrossRef]

55. Carroll, J.S.; Liu, X.S.; Brodsky, A.S.; Li, W.; Meyer, C.A.; Szary, A.J.; Eeckhoute, J.; Shao, W.; Hestermann, E.V.; Geistlinger, T.R.; et al. Chromosome-wide mapping of estrogen receptor binding reveals long-range regulation requiring the forkhead protein FoxA1. Cell 2005, 122, 33-43. [CrossRef] [PubMed]

56. Gertz, J.; Savic, D.; Varley, K.E.; Partridge, E.C.; Safi, A.; Jain, P.; Cooper, G.M.; Reddy, T.E.; Crawford, G.E.; Myers, R.M. Distinct properties of cell-type-specific and shared transcription factor binding sites. Mol. Cell 2013, 52, 25-36. [CrossRef]

57. Gao, H.; Falt, S.; Sandelin, A.; Gustafsson, J.A.; Dahlman-Wright, K. Genome-wide identification of estrogen receptor alphabinding sites in mouse liver. Mol. Endocrinol. 2008, 22, 10-22. [CrossRef]

58. Gao, H.; Bryzgalova, G.; Hedman, E.; Khan, A.; Efendic, S.; Gustafsson, J.A.; Dahlman-Wright, K. Long-term administration of estradiol decreases expression of hepatic lipogenic genes and improves insulin sensitivity in ob/ob mice: A possible mechanism is through direct regulation of signal transducer and activator of transcription 3. Mol. Endocrinol. 2006, 20, 1287-1299. [CrossRef]

59. Mohapatra, S.; Chakraborty, T.; Shimizu, S.; Ohta, K.; Nagahama, Y.; Ohta, K. Estrogen and estrogen receptors chauffeur the sex-biased autophagic action in liver. Cell Death Differ. 2020, 27, 3117-3130. [CrossRef]

60. Radenne, A.; Akpa, M.; Martel, C.; Sawadogo, S.; Mauvoisin, D.; Mounier, C. Hepatic regulation of fatty acid synthase by insulin and T3: Evidence for T3 genomic and nongenomic actions. Am. J. Physiol. Endocrinol. Metab. 2008, 295, E884-E894. [CrossRef]

61. Zhang, Y.; Yin, L.; Hillgartner, F.B. Thyroid hormone stimulates acetyl-coA carboxylase-alpha transcription in hepatocytes by modulating the composition of nuclear receptor complexes bound to a thyroid hormone response element. J. Biol. Chem. 2001, 276, 974-983. [CrossRef] [PubMed]

62. Hashimoto, K.; Yamada, M.; Matsumoto, S.; Monden, T.; Satoh, T.; Mori, M. Mouse sterol response element binding protein-1c gene expression is negatively regulated by thyroid hormone. Endocrinology 2006, 147, 4292-4302. [CrossRef] [PubMed]

63. Boergesen, M.; Pedersen, T.A.; Gross, B.; van Heeringen, S.J.; Hagenbeek, D.; Bindesboll, C.; Caron, S.; Lalloyer, F.; Steffensen, K.R.; Nebb, H.I.; et al. Genome-wide profiling of liver X receptor, retinoid X receptor, and peroxisome proliferator-activated receptor alpha in mouse liver reveals extensive sharing of binding sites. Mol. Cell Biol. 2012, 32, 852-867. [CrossRef] [PubMed]

64. Horlein, A.J.; Naar, A.M.; Heinzel, T.; Torchia, J.; Gloss, B.; Kurokawa, R.; Ryan, A.; Kamei, Y.; Soderstrom, M.; Glass, C.K.; et al. Ligand-independent repression by the thyroid hormone receptor mediated by a nuclear receptor co-repressor. Nature 1995, 377, 397-404. [CrossRef] [PubMed]

65. Ishizuka, T.; Lazar, M.A. The N-CoR/histone deacetylase 3 complex is required for repression by thyroid hormone receptor. Mol. Cell Biol. 2003, 23, 5122-5131. [CrossRef]

66. Xu, L.; Glass, C.K.; Rosenfeld, M.G. Coactivator and corepressor complexes in nuclear receptor function. Curr. Opin. Genet. Dev. 1999, 9, 140-147. [CrossRef]

67. Cable, E.E.; Finn, P.D.; Stebbins, J.W.; Hou, J.; Ito, B.R.; van Poelje, P.D.; Linemeyer, D.L.; Erion, M.D. Reduction of hepatic steatosis in rats and mice after treatment with a liver-targeted thyroid hormone receptor agonist. Hepatology 2009, 49, 407-417. [CrossRef]

68. Perra, A.; Simbula, G.; Simbula, M.; Pibiri, M.; Kowalik, M.A.; Sulas, P.; Cocco, M.T.; Ledda-Columbano, G.M.; Columbano, A. Thyroid hormone (T3) and TRbeta agonist GC-1 inhibit/reverse nonalcoholic fatty liver in rats. FASEB J. 2008, 22, $2981-2989$. [CrossRef] 
69. Sinha, R.A.; You, S.H.; Zhou, J.; Siddique, M.M.; Bay, B.H.; Zhu, X.; Privalsky, M.L.; Cheng, S.Y.; Stevens, R.D.; Summers, S.A.; et al. Thyroid hormone stimulates hepatic lipid catabolism via activation of autophagy. J. Clin. Investig. 2012, 122, 2428-2438. [CrossRef]

70. Tseng, Y.H.; Ke, P.Y.; Liao, C.J.; Wu, S.M.; Chi, H.C.; Tsai, C.Y.; Chen, C.Y.; Lin, Y.H.; Lin, K.H. Chromosome 19 open reading frame 80 is upregulated by thyroid hormone and modulates autophagy and lipid metabolism. Autophagy 2014, 10, 20-31. [CrossRef]

71. Sinha, R.A.; Singh, B.K.; Zhou, J.; Wu, Y.; Farah, B.L.; Ohba, K.; Lesmana, R.; Gooding, J.; Bay, B.H.; Yen, P.M. Thyroid hormone induction of mitochondrial activity is coupled to mitophagy via ROS-AMPK-ULK1 signaling. Autophagy 2015, 11, 1341-1357. [CrossRef] [PubMed]

72. Singh, B.K.; Sinha, R.A.; Tripathi, M.; Mendoza, A.; Ohba, K.; Sy, J.A.C.; Xie, S.Y.; Zhou, J.; Ho, J.P.; Chang, C.Y.; et al. Thyroid hormone receptor and ERRalpha coordinately regulate mitochondrial fission, mitophagy, biogenesis, and function. Sci. Signal. 2018, 11. [CrossRef] [PubMed]

73. Chi, H.C.; Chen, S.L.; Tsai, C.Y.; Chuang, W.Y.; Huang, Y.H.; Tsai, M.M.; Wu, S.M.; Sun, C.P.; Yeh, C.T.; Lin, K.H. Thyroid hormone suppresses hepatocarcinogenesis via DAPK2 and SQSTM1-dependent selective autophagy. Autophagy 2016, 12, 2271-2285. [CrossRef] [PubMed]

74. Sachdeva, N.; Asthana, V.; Brewer, T.H.; Garcia, D.; Asthana, D. Impaired restoration of plasmacytoid dendritic cells in HIV1-infected patients with poor CD4 T cell reconstitution is associated with decrease in capacity to produce IFN-alpha but not proinflammatory cytokines. J. Immunol. 2008, 181, 2887-2897. [CrossRef]

75. Goltzman, D.; Miao, D.; Panda, D.K.; Hendy, G.N. Effects of calcium and of the Vitamin D system on skeletal and calcium homeostasis: Lessons from genetic models. J. Steroid. Biochem. Mol. Biol. 2004, 89-90, 485-489. [CrossRef]

76. Makishima, M.; Lu, T.T.; Xie, W.; Whitfield, G.K.; Domoto, H.; Evans, R.M.; Haussler, M.R.; Mangelsdorf, D.J. Vitamin D receptor as an intestinal bile acid sensor. Science 2002, 296, 1313-1316. [CrossRef] [PubMed]

77. Nagpal, S.; Na, S.; Rathnachalam, R. Noncalcemic actions of vitamin D receptor ligands. Endocr. Rev. 2005, 26, 662-687. [CrossRef]

78. Cheskis, B.; Freedman, L.P. Ligand modulates the conversion of DNA-bound vitamin D3 receptor (VDR) homodimers into VDR-retinoid X receptor heterodimers. Mol. Cell Biol. 1994, 14, 3329-3338. [CrossRef]

79. Meyer, M.B.; Pike, J.W. Corepressors (NCoR and SMRT) as well as coactivators are recruited to positively regulated 1alpha,25dihydroxyvitamin D3-responsive genes. J. Steroid. Biochem. Mol. Biol. 2013, 136, 120-124. [CrossRef]

80. Bookout, A.L.; Jeong, Y.; Downes, M.; Yu, R.T.; Evans, R.M.; Mangelsdorf, D.J. Anatomical profiling of nuclear receptor expression reveals a hierarchical transcriptional network. Cell 2006, 126, 789-799. [CrossRef]

81. Gascon-Barre, M.; Demers, C.; Mirshahi, A.; Neron, S.; Zalzal, S.; Nanci, A. The normal liver harbors the vitamin D nuclear receptor in nonparenchymal and biliary epithelial cells. Hepatology 2003, 37, 1034-1042. [CrossRef] [PubMed]

82. Ding, N.; Yu, R.T.; Subramaniam, N.; Sherman, M.H.; Wilson, C.; Rao, R.; Leblanc, M.; Coulter, S.; He, M.; Scott, C.; et al. A vitamin D receptor/SMAD genomic circuit gates hepatic fibrotic response. Cell 2013, 153, 601-613. [CrossRef] [PubMed]

83. Nakano, T.; Cheng, Y.F.; Lai, C.Y.; Hsu, L.W.; Chang, Y.C.; Deng, J.Y.; Huang, Y.Z.; Honda, H.; Chen, K.D.; Wang, C.C.; et al. Impact of artificial sunlight therapy on the progress of non-alcoholic fatty liver disease in rats. J. Hepatol. 2011, 55, 415-425. [CrossRef]

84. Li, R.; Guo, E.; Yang, J.; Li, A.; Yang, Y.; Liu, S.; Liu, A.; Jiang, X. 1,25(OH) ${ }_{2} \mathrm{D}_{3}$ attenuates hepatic steatosis by inducing autophagy in mice. Obesity 2017, 25, 561-571. [CrossRef] [PubMed]

85. Yuan, F.; Xu, Y.; You, K.; Zhang, J.; Yang, F.; Li, Y.X. Calcitriol alleviates ethanol-induced hepatotoxicity via AMPK/mTORmediated autophagy. Arch. Biochem. Biophys. 2021, 697, 108694. [CrossRef] [PubMed]

86. Inagaki, T.; Choi, M.; Moschetta, A.; Peng, L.; Cummins, C.L.; McDonald, J.G.; Luo, G.; Jones, S.A.; Goodwin, B.; Richardson, J.A.; et al. Fibroblast growth factor 15 functions as an enterohepatic signal to regulate bile acid homeostasis. Cell Metab. 2005, 2, 217-225. [CrossRef] [PubMed]

87. Kir, S.; Beddow, S.A.; Samuel, V.T.; Miller, P.; Previs, S.F.; Suino-Powell, K.; Xu, H.E.; Shulman, G.I.; Kliewer, S.A.; Mangelsdorf, D.J. FGF19 as a postprandial, insulin-independent activator of hepatic protein and glycogen synthesis. Science 2011, 331, 1621-1624. [CrossRef] [PubMed]

88. Massafra, V.; van Mil, S.W.C. Farnesoid X receptor: A “homeostat” for hepatic nutrient metabolism. Biochim. Biophys. Acta Mol. Basis Dis. 2018, 1864, 45-59. [CrossRef] [PubMed]

89. Sun, L.; Cai, J.; Gonzalez, F.J. The role of farnesoid X receptor in metabolic diseases, and gastrointestinal and liver cancer. Nat. Rev. Gastroenterol. Hepatol. 2021, 18, 335-347. [CrossRef]

90. Wang, Y.D.; Chen, W.D.; Moore, D.D.; Huang, W. FXR: A metabolic regulator and cell protector. Cell Res. 2008, 18, 1087-1095. [CrossRef]

91. Kalaany, N.Y.; Mangelsdorf, D.J. LXRS and FXR: The yin and yang of cholesterol and fat metabolism. Annu. Rev. Physiol. 2006, 68, 159-191. [CrossRef] [PubMed]

92. Chawla, A.; Saez, E.; Evans, R.M. Don't know much bile-ology. Cell 2000, 103, 1-4. [CrossRef]

93. Huang, W.; Ma, K.; Zhang, J.; Qatanani, M.; Cuvillier, J.; Liu, J.; Dong, B.; Huang, X.; Moore, D.D. Nuclear receptor-dependent bile acid signaling is required for normal liver regeneration. Science 2006, 312, 233-236. [CrossRef]

94. Ryan, K.K.; Tremaroli, V.; Clemmensen, C.; Kovatcheva-Datchary, P.; Myronovych, A.; Karns, R.; Wilson-Perez, H.E.; Sandoval, D.A.; Kohli, R.; Backhed, F.; et al. FXR is a molecular target for the effects of vertical sleeve gastrectomy. Nature 2014, 509, 183-188. [CrossRef] 
95. Tu, H.; Okamoto, A.Y.; Shan, B. FXR, a bile acid receptor and biological sensor. Trends Cardiovasc. Med. 2000, 10, 30-35. [CrossRef]

96. Makishima, M.; Okamoto, A.Y.; Repa, J.J.; Tu, H.; Learned, R.M.; Luk, A.; Hull, M.V.; Lustig, K.D.; Mangelsdorf, D.J.; Shan, B. Identification of a nuclear receptor for bile acids. Science 1999, 284, 1362-1365. [CrossRef]

97. Parks, D.J.; Blanchard, S.G.; Bledsoe, R.K.; Chandra, G.; Consler, T.G.; Kliewer, S.A.; Stimmel, J.B.; Willson, T.M.; Zavacki, A.M.; Moore, D.D.; et al. Bile acids: Natural ligands for an orphan nuclear receptor. Science 1999, 284, 1365-1368. [CrossRef]

98. Wang, H.; Chen, J.; Hollister, K.; Sowers, L.C.; Forman, B.M. Endogenous bile acids are ligands for the nuclear receptor FXR/BAR. Mol. Cell 1999, 3, 543-553. [CrossRef]

99. Sayin, S.I.; Wahlstrom, A.; Felin, J.; Jantti, S.; Marschall, H.U.; Bamberg, K.; Angelin, B.; Hyotylainen, T.; Oresic, M.; Backhed, F. Gut microbiota regulates bile acid metabolism by reducing the levels of tauro-beta-muricholic acid, a naturally occurring FXR antagonist. Cell Metab. 2013, 17, 225-235. [CrossRef]

100. Li, F.; Jiang, C.; Krausz, K.W.; Li, Y.; Albert, I.; Hao, H.; Fabre, K.M.; Mitchell, J.B.; Patterson, A.D.; Gonzalez, F.J. Microbiome remodelling leads to inhibition of intestinal farnesoid $X$ receptor signalling and decreased obesity. Nat. Commun. 2013, 4, 2384. [CrossRef]

101. Pellicciari, R.; Fiorucci, S.; Camaioni, E.; Clerici, C.; Costantino, G.; Maloney, P.R.; Morelli, A.; Parks, D.J.; Willson, T.M. 6alphaethyl-chenodeoxycholic acid (6-ECDCA), a potent and selective FXR agonist endowed with anticholestatic activity. J. Med. Chem. 2002, 45, 3569-3572. [CrossRef] [PubMed]

102. Maloney, P.R.; Parks, D.J.; Haffner, C.D.; Fivush, A.M.; Chandra, G.; Plunket, K.D.; Creech, K.L.; Moore, L.B.; Wilson, J.G.; Lewis, M.C.; et al. Identification of a chemical tool for the orphan nuclear receptor FXR. J. Med. Chem. 2000, 43, 2971-2974. [CrossRef] [PubMed]

103. Downes, M.; Verdecia, M.A.; Roecker, A.J.; Hughes, R.; Hogenesch, J.B.; Kast-Woelbern, H.R.; Bowman, M.E.; Ferrer, J.L.; Anisfeld, A.M.; Edwards, P.A.; et al. A chemical, genetic, and structural analysis of the nuclear bile acid receptor FXR. Mol. Cell 2003, 11, 1079-1092. [CrossRef]

104. Urizar, N.L.; Liverman, A.B.; Dodds, D.T.; Silva, F.V.; Ordentlich, P.; Yan, Y.; Gonzalez, F.J.; Heyman, R.A.; Mangelsdorf, D.J.; Moore, D.D. A natural product that lowers cholesterol as an antagonist ligand for FXR. Science 2002, 296, 1703-1706. [CrossRef]

105. Ricketts, M.L.; Boekschoten, M.V.; Kreeft, A.J.; Hooiveld, G.J.; Moen, C.J.; Muller, M.; Frants, R.R.; Kasanmoentalib, S.; Post, S.M.; Princen, H.M.; et al. The cholesterol-raising factor from coffee beans, cafestol, as an agonist ligand for the farnesoid and pregnane X receptors. Mol. Endocrinol. 2007, 21, 1603-1616. [CrossRef]

106. Zhou, H.; Hylemon, P.B. Bile acids are nutrient signaling hormones. Steroids 2014, 86, 62-68. [CrossRef]

107. Panzitt, K.; Wagner, M. FXR in liver physiology: Multiple faces to regulate liver metabolism. Biochim. Biophys. Acta Mol. Basis Dis. 2021, 1867, 166133. [CrossRef]

108. Kim, K.H.; Moore, D.D. Regulation of Liver Energy Balance by the Nuclear Receptors Farnesoid X Receptor and Peroxisome Proliferator Activated Receptor alpha. Dig. Dis. 2017, 35, 203-209. [CrossRef]

109. Preidis, G.A.; Kim, K.H.; Moore, D.D. Nutrient-sensing nuclear receptors PPARalpha and FXR control liver energy balance. J. Clin. Investig. 2017, 127, 1193-1201. [CrossRef]

110. Williams, J.A.; Thomas, A.M.; Li, G.; Kong, B.; Zhan, L.; Inaba, Y.; Xie, W.; Ding, W.X.; Guo, G.L. Tissue specific induction of p62/Sqstm1 by farnesoid X receptor. PLoS ONE 2012, 7, e43961. [CrossRef]

111. Manley, S.; Ni, H.M.; Kong, B.; Apte, U.; Guo, G.; Ding, W.X. Suppression of autophagic flux by bile acids in hepatocytes. Toxicol. Sci. 2014, 137, 478-490. [CrossRef]

112. Seok, S.; Fu, T.; Choi, S.E.; Li, Y.; Zhu, R.; Kumar, S.; Sun, X.; Yoon, G.; Kang, Y.; Zhong, W.; et al. Transcriptional regulation of autophagy by an FXR-CREB axis. Nature 2014, 516, 108-111. [CrossRef]

113. Lee, J.M.; Wagner, M.; Xiao, R.; Kim, K.H.; Feng, D.; Lazar, M.A.; Moore, D.D. Nutrient-sensing nuclear receptors coordinate autophagy. Nature 2014, 516, 112-115. [CrossRef]

114. Settembre, C.; Ballabio, A. Cell metabolism: Autophagy transcribed. Nature 2014, 516, 40-41. [CrossRef]

115. Kim, K.H.; Choi, S.; Zhou, Y.; Kim, E.Y.; Lee, J.M.; Saha, P.K.; Anakk, S.; Moore, D.D. Hepatic FXR/SHP axis modulates systemic glucose and fatty acid homeostasis in aged mice. Hepatology 2017, 66, 498-509. [CrossRef]

116. Manley, S.; Ni, H.M.; Williams, J.A.; Kong, B.; DiTacchio, L.; Guo, G.; Ding, W.X. Farnesoid X receptor regulates forkhead Box O3a activation in ethanol-induced autophagy and hepatotoxicity. Redox Biol. 2014, 2, 991-1002. [CrossRef]

117. Mueller, M.; Thorell, A.; Claudel, T.; Jha, P.; Koefeler, H.; Lackner, C.; Hoesel, B.; Fauler, G.; Stojakovic, T.; Einarsson, C.; et al Ursodeoxycholic acid exerts farnesoid X receptor-antagonistic effects on bile acid and lipid metabolism in morbid obesity. J. Hepatol. 2015, 62, 1398-1404. [CrossRef]

118. Panzitt, K.; Jungwirth, E.; Krones, E.; Lee, J.M.; Pollheimer, M.; Thallinger, G.G.; Kolb-Lenz, D.; Xiao, R.; Thorell, A.; Trauner, M.; et al. FXR-dependent Rubicon induction impairs autophagy in models of human cholestasis. J. Hepatol. 2020, 72, 1122-1131. [CrossRef]

119. Panzitt, K.; Fickert, P.; Wagner, M. Regulation of autophagy by bile acids and in cholestasis-CholestoPHAGY or CholeSTOPagy. Biochim. Biophys. Acta Mol. Basis Dis. 2021, 1867, 166017. [CrossRef]

120. Gearing, K.L.; Gottlicher, M.; Teboul, M.; Widmark, E.; Gustafsson, J.A. Interaction of the peroxisome-proliferator-activated receptor and retinoid X receptor. Proc. Natl. Acad. Sci. USA 1993, 90, 1440-1444. [CrossRef]

121. Miyata, K.S.; McCaw, S.E.; Marcus, S.L.; Rachubinski, R.A.; Capone, J.P. The peroxisome proliferator-activated receptor interacts with the retinoid $X$ receptor in vivo. Gene 1994, 148, 327-330. [CrossRef] 
122. Bardot, O.; Aldridge, T.C.; Latruffe, N.; Green, S. PPAR-RXR heterodimer activates a peroxisome proliferator response element upstream of the bifunctional enzyme gene. Biochem. Biophys. Res. Commun. 1993, 192, 37-45. [CrossRef]

123. Schoonjans, K.; Peinado-Onsurbe, J.; Lefebvre, A.M.; Heyman, R.A.; Briggs, M.; Deeb, S.; Staels, B.; Auwerx, J. PPARalpha and PPARgamma activators direct a distinct tissue-specific transcriptional response via a PPRE in the lipoprotein lipase gene. EMBO J. 1996, 15, 5336-5348. [CrossRef] [PubMed]

124. Issemann, I.; Green, S. Activation of a member of the steroid hormone receptor superfamily by peroxisome proliferators. Nature 1990, 347, 645-650. [CrossRef] [PubMed]

125. Dreyer, C.; Krey, G.; Keller, H.; Givel, F.; Helftenbein, G.; Wahli, W. Control of the peroxisomal beta-oxidation pathway by a novel family of nuclear hormone receptors. Cell 1992, 68, 879-887. [CrossRef]

126. Kliewer, S.A.; Forman, B.M.; Blumberg, B.; Ong, E.S.; Borgmeyer, U.; Mangelsdorf, D.J.; Umesono, K.; Evans, R.M. Differential expression and activation of a family of murine peroxisome proliferator-activated receptors. Proc. Natl. Acad. Sci. USA 1994, 91, 7355-7359. [CrossRef]

127. Tontonoz, P.; Hu, E.; Spiegelman, B.M. Stimulation of adipogenesis in fibroblasts by PPAR gamma 2, a lipid-activated transcription factor. Cell 1994, 79, 1147-1156. [CrossRef]

128. Wang, Y.X.; Lee, C.H.; Tiep, S.; Yu, R.T.; Ham, J.; Kang, H.; Evans, R.M. Peroxisome-proliferator-activated receptor delta activates fat metabolism to prevent obesity. Cell 2003, 113, 159-170. [CrossRef]

129. Kliewer, S.A.; Lenhard, J.M.; Willson, T.M.; Patel, I.; Morris, D.C.; Lehmann, J.M. A prostaglandin J2 metabolite binds peroxisome proliferator-activated receptor gamma and promotes adipocyte differentiation. Cell 1995, 83, 813-819. [CrossRef]

130. Watts, G.F.; Dimmitt, S.B. Fibrates, dyslipoproteinaemia and cardiovascular disease. Curr. Opin. Lipidol. 1999, 10, 561-574. [CrossRef]

131. Lehmann, J.M.; Moore, L.B.; Smith-Oliver, T.A.; Wilkison, W.O.; Willson, T.M.; Kliewer, S.A. An antidiabetic thiazolidinedione is a high affinity ligand for peroxisome proliferator-activated receptor gamma (PPAR gamma). J. Biol. Chem. 1995, 270, 12953-12956. [CrossRef]

132. Forman, B.M.; Tontonoz, P.; Chen, J.; Brun, R.P.; Spiegelman, B.M.; Evans, R.M. 15-Deoxy-delta 12, 14-prostaglandin J2 is a ligand for the adipocyte determination factor PPAR gamma. Cell 1995, 83, 803-812. [CrossRef]

133. Luquet, S.; Lopez-Soriano, J.; Holst, D.; Fredenrich, A.; Melki, J.; Rassoulzadegan, M.; Grimaldi, P.A. Peroxisome proliferatoractivated receptor delta controls muscle development and oxidative capability. FASEB J. 2003, 17, 2299-2301. [CrossRef]

134. Wang, Y.X.; Zhang, C.L.; Yu, R.T.; Cho, H.K.; Nelson, M.C.; Bayuga-Ocampo, C.R.; Ham, J.; Kang, H.; Evans, R.M. Regulation of muscle fiber type and running endurance by PPARdelta. PLoS Biol. 2004, 2, e294. [CrossRef] [PubMed]

135. Narkar, V.A.; Downes, M.; Yu, R.T.; Embler, E.; Wang, Y.X.; Banayo, E.; Mihaylova, M.M.; Nelson, M.C.; Zou, Y.; Juguilon, H.; et al. AMPK and PPARdelta agonists are exercise mimetics. Cell 2008, 134, 405-415. [CrossRef]

136. Fan, W.; Waizenegger, W.; Lin, C.S.; Sorrentino, V.; He, M.X.; Wall, C.E.; Li, H.; Liddle, C.; Yu, R.T.; Atkins, A.R.; et al. PPARdelta Promotes Running Endurance by Preserving Glucose. Cell Metab. 2017, 25, 1186-1193.e1184. [CrossRef]

137. Sardiello, M.; Palmieri, M.; di Ronza, A.; Medina, D.L.; Valenza, M.; Gennarino, V.A.; Di Malta, C.; Donaudy, F.; Embrione, V.; Polishchuk, R.S.; et al. A gene network regulating lysosomal biogenesis and function. Science 2009, 325, 473-477. [CrossRef]

138. Settembre, C.; Di Malta, C.; Polito, V.A.; Garcia Arencibia, M.; Vetrini, F.; Erdin, S.; Erdin, S.U.; Huynh, T.; Medina, D.; Colella, P.; et al. TFEB links autophagy to lysosomal biogenesis. Science 2011, 332, 1429-1433. [CrossRef] [PubMed]

139. Settembre, C.; De Cegli, R.; Mansueto, G.; Saha, P.K.; Vetrini, F.; Visvikis, O.; Huynh, T.; Carissimo, A.; Palmer, D.; Klisch, T.J.; et al. TFEB controls cellular lipid metabolism through a starvation-induced autoregulatory loop. Nat. Cell Biol. 2013, 15, 647-658. [CrossRef]

140. Settembre, C.; Ballabio, A. TFEB regulates autophagy: An integrated coordination of cellular degradation and recycling processes Autophagy 2011, 7, 1379-1381. [CrossRef] [PubMed]

141. Settembre, C.; Zoncu, R.; Medina, D.L.; Vetrini, F.; Erdin, S.; Erdin, S.; Huynh, T.; Ferron, M.; Karsenty, G.; Vellard, M.C.; et al. A lysosome-to-nucleus signalling mechanism senses and regulates the lysosome via mTOR and TFEB. EMBO J. 2012, 31, 1095-1108. [CrossRef] [PubMed]

142. Settembre, C.; Fraldi, A.; Medina, D.L.; Ballabio, A. Signals from the lysosome: A control centre for cellular clearance and energy metabolism. Nat. Rev. Mol. Cell Biol. 2013, 14, 283-296. [CrossRef]

143. Singh, R.; Kaushik, S.; Wang, Y.; Xiang, Y.; Novak, I.; Komatsu, M.; Tanaka, K.; Cuervo, A.M.; Czaja, M.J. Autophagy regulates lipid metabolism. Nature 2009, 458, 1131-1135. [CrossRef]

144. Singh, R.; Cuervo, A.M. Lipophagy: Connecting autophagy and lipid metabolism. Int. J. Cell Biol. 2012, 2012, 282041. [CrossRef] [PubMed]

145. Liu, K.; Czaja, M.J. Regulation of lipid stores and metabolism by lipophagy. Cell Death Differ. 2013, 20, 3-11. [CrossRef]

146. Bocos, C.; Gottlicher, M.; Gearing, K.; Banner, C.; Enmark, E.; Teboul, M.; Crickmore, A.; Gustafsson, J.A. Fatty acid activation of peroxisome proliferator-activated receptor (PPAR). J. Steroid Biochem. Mol. Biol. 1995, 53, 467-473. [CrossRef]

147. Sinha, R.A.; Rajak, S.; Singh, B.K.; Yen, P.M. Hepatic Lipid Catabolism via PPARalpha-Lysosomal Crosstalk. Int. J. Mol. Sci. 2020, 21, 2391. [CrossRef] [PubMed]

148. Jiao, M.; Ren, F.; Zhou, L.; Zhang, X.; Zhang, L.; Wen, T.; Wei, L.; Wang, X.; Shi, H.; Bai, L.; et al. Peroxisome proliferator-activated receptor alpha activation attenuates the inflammatory response to protect the liver from acute failure by promoting the autophagy pathway. Cell Death Dis. 2014, 5, e1397. [CrossRef] [PubMed] 
149. Ren, F.; Zhang, L.; Zhang, X.; Shi, H.; Wen, T.; Bai, L.; Zheng, S.; Chen, Y.; Chen, D.; Li, L.; et al. Inhibition of glycogen synthase kinase 3beta promotes autophagy to protect mice from acute liver failure mediated by peroxisome proliferator-activated receptor alpha. Cell Death Dis. 2016, 7, e2151. [CrossRef]

150. Liu, Y.M.; Ma, J.H.; Zeng, Q.L.; Lv, J.; Xie, X.H.; Pan, Y.J.; Yu, Z.J. MiR-19a Affects Hepatocyte Autophagy via Regulating lncRNA NBR2 and AMPK/PPARalpha in D-GalN/Lipopolysaccharide-Stimulated Hepatocytes. J. Cell Biochem. 2018, 119, 358-365. [CrossRef] [PubMed]

151. Inagaki, T.; Dutchak, P.; Zhao, G.; Ding, X.; Gautron, L.; Parameswara, V.; Li, Y.; Goetz, R.; Mohammadi, M.; Esser, V.; et al. Endocrine regulation of the fasting response by PPARalpha-mediated induction of fibroblast growth factor 21. Cell Metab. 2007, 5, 415-425. [CrossRef]

152. Potthoff, M.J.; Inagaki, T.; Satapati, S.; Ding, X.; He, T.; Goetz, R.; Mohammadi, M.; Finck, B.N.; Mangelsdorf, D.J.; Kliewer, S.A.; et al. FGF21 induces PGC-1alpha and regulates carbohydrate and fatty acid metabolism during the adaptive starvation response. Proc. Natl. Acad. Sci. USA 2009, 106, 10853-10858. [CrossRef]

153. Kliewer, S.A.; Mangelsdorf, D.J. Fibroblast growth factor 21: From pharmacology to physiology. Am. J. Clin. Nutr. 2010, 91, 254S-257S. [CrossRef]

154. Zhang, Y.; Pan, Y.; Xiong, R.; Zheng, J.; Li, Q.; Zhang, S.; Li, X.; Pan, X.; Yang, S. FGF21 mediates the protective effect of fenofibrate against acetaminophen -induced hepatotoxicity via activating autophagy in mice. Biochem. Biophys. Res. Commun. 2018, 503, 474-481. [CrossRef]

155. Byun, S.; Seok, S.; Kim, Y.C.; Zhang, Y.; Yau, P.; Iwamori, N.; Xu, H.E.; Ma, J.; Kemper, B.; Kemper, J.K. Fasting-induced FGF21 signaling activates hepatic autophagy and lipid degradation via JMJD3 histone demethylase. Nat. Commun. 2020, $11,807$. [CrossRef]

156. Wei, C.C.; Luo, Z.; Hogstrand, C.; Xu, Y.H.; Wu, L.X.; Chen, G.H.; Pan, Y.X.; Song, Y.F. Zinc reduces hepatic lipid deposition and activates lipophagy via $\mathrm{Zn}(2+) / \mathrm{MTF}-1 /$ PPARalpha and $\mathrm{Ca}(2+) /$ CaMKKbeta/AMPK pathways. FASEB J. 2018, 32, 6666-6680. [CrossRef]

157. Hernandez-Gea, V.; Ghiassi-Nejad, Z.; Rozenfeld, R.; Gordon, R.; Fiel, M.I.; Yue, Z.; Czaja, M.J.; Friedman, S.L. Autophagy releases lipid that promotes fibrogenesis by activated hepatic stellate cells in mice and in human tissues. Gastroenterology 2012, 142, 938-946. [CrossRef]

158. Wang, Z.; Tao, Y.; Qiu, T.; Yao, X.; Jiang, L.; Wang, N.; Wei, S.; Jia, X.; Pei, P.; Yang, G.; et al. Taurine protected As2O3-induced the activation of hepatic stellate cells through inhibiting PPARalpha-autophagy pathway. Chem. Biol. Interact. 2019, 300, 123-130. [CrossRef]

159. Saito, T.; Kuma, A.; Sugiura, Y.; Ichimura, Y.; Obata, M.; Kitamura, H.; Okuda, S.; Lee, H.C.; Ikeda, K.; Kanegae, Y.; et al. Autophagy regulates lipid metabolism through selective turnover of NCoR1. Nat. Commun. 2019, 10, 1567. [CrossRef]

160. Iershov, A.; Nemazanyy, I.; Alkhoury, C.; Girard, M.; Barth, E.; Cagnard, N.; Montagner, A.; Chretien, D.; Rugarli, E.I.; Guillou, H.; et al. The class 3 PI3K coordinates autophagy and mitochondrial lipid catabolism by controlling nuclear receptor PPARalpha. Nat. Commun. 2019, 10, 1566. [CrossRef]

161. Vara, D.; Morell, C.; Rodriguez-Henche, N.; Diaz-Laviada, I. Involvement of PPARgamma in the antitumoral action of cannabinoids on hepatocellular carcinoma. Cell Death Dis. 2013, 4, e618. [CrossRef]

162. Hsiao, P.J.; Chiou, H.C.; Jiang, H.J.; Lee, M.Y.; Hsieh, T.J.; Kuo, K.K. Pioglitazone Enhances Cytosolic Lipolysis, beta-oxidation and Autophagy to Ameliorate Hepatic Steatosis. Sci. Rep. 2017, 7, 9030. [CrossRef]

163. Bai, J.; Yao, X.; Jiang, L.; Zhang, Q.; Guan, H.; Liu, S.; Wu, W.; Qiu, T.; Gao, N.; Yang, L.; et al. Taurine protects against As2O3-induced autophagy in livers of rat offsprings through PPARgamma pathway. Sci. Rep. 2016, 6, 27733. [CrossRef]

164. Tong, L.; Wang, L.; Yao, S.; Jin, L.; Yang, J.; Zhang, Y.; Ning, G.; Zhang, Z. PPARdelta attenuates hepatic steatosis through autophagy-mediated fatty acid oxidation. Cell Death Dis. 2019, 10, 197. [CrossRef]

165. Willy, P.J.; Umesono, K.; Ong, E.S.; Evans, R.M.; Heyman, R.A.; Mangelsdorf, D.J. LXR, a nuclear receptor that defines a distinct retinoid response pathway. Genes Dev. 1995, 9, 1033-1045. [CrossRef]

166. Repa, J.J.; Mangelsdorf, D.J. The role of orphan nuclear receptors in the regulation of cholesterol homeostasis. Annu. Rev. Cell Dev. Biol. 2000, 16, 459-481. [CrossRef]

167. Zhang, Y.; Breevoort, S.R.; Angdisen, J.; Fu, M.; Schmidt, D.R.; Holmstrom, S.R.; Kliewer, S.A.; Mangelsdorf, D.J.; Schulman, I.G. Liver LXRalpha expression is crucial for whole body cholesterol homeostasis and reverse cholesterol transport in mice. J. Clin. Investig. 2012, 122, 1688-1699. [CrossRef]

168. Peet, D.J.; Turley, S.D.; Ma, W.; Janowski, B.A.; Lobaccaro, J.M.; Hammer, R.E.; Mangelsdorf, D.J. Cholesterol and bile acid metabolism are impaired in mice lacking the nuclear oxysterol receptor LXR alpha. Cell 1998, 93, 693-704. [CrossRef]

169. Repa, J.J.; Liang, G.; Ou, J.; Bashmakov, Y.; Lobaccaro, J.M.; Shimomura, I.; Shan, B.; Brown, M.S.; Goldstein, J.L.; Mangelsdorf, D.J. Regulation of mouse sterol regulatory element-binding protein-1c gene (SREBP-1c) by oxysterol receptors, LXRalpha and LXRbeta. Genes Dev. 2000, 14, 2819-2830. [CrossRef]

170. Schultz, J.R.; Tu, H.; Luk, A.; Repa, J.J.; Medina, J.C.; Li, L.; Schwendner, S.; Wang, S.; Thoolen, M.; Mangelsdorf, D.J.; et al. Role of LXRs in control of lipogenesis. Genes Dev. 2000, 14, 2831-2838. [CrossRef]

171. Kim, Y.S.; Nam, H.J.; Han, C.Y.; Joo, M.S.; Jang, K.; Jun, D.W.; Kim, S.G. Liver X Receptor Alpha Activation Inhibits Autophagy and Lipophagy in Hepatocytes by Dysregulating Autophagy-Related 4B Cysteine Peptidase and Rab-8B, Reducing Mitochondrial Fuel Oxidation. Hepatology 2021, 73, 1307-1326. [CrossRef] 
172. Silvente-Poirot, S.; Segala, G.; Poirot, M.C.; Poirot, M. Ligand-dependent transcriptional induction of lethal autophagy: A new perspective for cancer treatment. Autophagy 2018, 14, 555-557. [CrossRef]

173. Kliewer, S.A. The nuclear pregnane X receptor regulates xenobiotic detoxification. J. Nutr 2003, 133, 2444S-2447S. [CrossRef]

174. Willson, T.M.; Kliewer, S.A. PXR, CAR and drug metabolism. Nat. Rev. Drug Discov. 2002, 1, 259-266. [CrossRef]

175. Frank, C.; Makkonen, H.; Dunlop, T.W.; Matilainen, M.; Vaisanen, S.; Carlberg, C. Identification of pregnane X receptor binding sites in the regulatory regions of genes involved in bile acid homeostasis. J. Mol. Biol. 2005, 346, 505-519. [CrossRef]

176. Cui, J.Y.; Gunewardena, S.S.; Rockwell, C.E.; Klaassen, C.D. ChIPing the cistrome of PXR in mouse liver. Nucleic Acids Res. 2010, 38, 7943-7963. [CrossRef]

177. Yan, L.; Chen, Z.; Wu, L.; Su, Y.; Wang, X.; Tang, N. Inhibitory effect of PXR on ammonia-induced hepatocyte autophagy via P53. Toxicol. Lett. 2018, 295, 153-161. [CrossRef]

178. Wu, S.; Lu, H.; Wang, W.; Song, L.; Liu, M.; Cao, Y.; Qi, X.; Sun, J.; Gong, L. Prevention of D-GalN/LPS-induced ALI by 18beta-glycyrrhetinic acid through PXR-mediated inhibition of autophagy degradation. Cell Death Dis. 2021, 12, 480. [CrossRef]

179. Wei, P.; Zhang, J.; Egan-Hafley, M.; Liang, S.; Moore, D.D. The nuclear receptor CAR mediates specific xenobiotic induction of drug metabolism. Nature 2000, 407, 920-923. [CrossRef]

180. Baes, M.; Gulick, T.; Choi, H.S.; Martinoli, M.G.; Simha, D.; Moore, D.D. A new orphan member of the nuclear hormone receptor superfamily that interacts with a subset of retinoic acid response elements. Mol. Cell Biol. 1994, 14, 1544-1552. [CrossRef]

181. Honkakoski, P.; Zelko, I.; Sueyoshi, T.; Negishi, M. The nuclear orphan receptor CAR-retinoid X receptor heterodimer activates the phenobarbital-responsive enhancer module of the CYP2B gene. Mol. Cell Biol. 1998, 18, 5652-5658. [CrossRef] [PubMed]

182. Zhang, L.; Yang, F.; Li, Y.; Cao, H.; Huang, A.; Zhuang, Y.; Zhang, C.; Hu, G.; Mao, Y.; Luo, J.; et al. The protection of selenium against cadmium-induced mitophagy via modulating nuclear xenobiotic receptors response and oxidative stress in the liver of rabbits. Environ. Pollut. 2021, 285, 117301. [CrossRef] [PubMed]

183. Li, J.; Ning, G.; Duncan, S.A. Mammalian hepatocyte differentiation requires the transcription factor HNF-4alpha. Genes Dev. 2000, 14, 464-474. [CrossRef] [PubMed]

184. Watt, A.J.; Garrison, W.D.; Duncan, S.A. HNF4: A central regulator of hepatocyte differentiation and function. Hepatology 2003, 37, 1249-1253. [CrossRef] [PubMed]

185. Hertz, R.; Magenheim, J.; Berman, I.; Bar-Tana, J. Fatty acyl-CoA thioesters are ligands of hepatic nuclear factor-4alpha. Nature 1998, 392, 512-516. [CrossRef]

186. Kiselyuk, A.; Lee, S.H.; Farber-Katz, S.; Zhang, M.; Athavankar, S.; Cohen, T.; Pinkerton, A.B.; Ye, M.; Bushway, P.; Richardson, A.D.; et al. HNF4alpha antagonists discovered by a high-throughput screen for modulators of the human insulin promoter. Chem. Biol. 2012, 19, 806-818. [CrossRef]

187. Thomas, A.M.; Hart, S.N.; Li, G.; Lu, H.; Fang, Y.; Fang, J.; Zhong, X.B.; Guo, G.L. Hepatocyte nuclear factor 4 alpha and farnesoid $X$ receptor co-regulates gene transcription in mouse livers on a genome-wide scale. Pharm. Res. 2013, 30, 2188-2198. [CrossRef]

188. Bhalla, S.; Ozalp, C.; Fang, S.; Xiang, L.; Kemper, J.K. Ligand-activated pregnane X receptor interferes with HNF-4 signaling by targeting a common coactivator PGC-1alpha. Functional implications in hepatic cholesterol and glucose metabolism. J. Biol. Chem. 2004, 279, 45139-45147. [CrossRef]

189. Miao, J.; Fang, S.; Bae, Y.; Kemper, J.K. Functional inhibitory cross-talk between constitutive androstane receptor and hepatic nuclear factor-4 in hepatic lipid/glucose metabolism is mediated by competition for binding to the DR1 motif and to the common coactivators, GRIP-1 and PGC-1alpha. J. Biol. Chem. 2006, 281, 14537-14546. [CrossRef]

190. Hayhurst, G.P.; Lee, Y.H.; Lambert, G.; Ward, J.M.; Gonzalez, F.J. Hepatocyte nuclear factor 4alpha (nuclear receptor 2A1) is essential for maintenance of hepatic gene expression and lipid homeostasis. Mol. Cell Biol. 2001, 21, 1393-1403. [CrossRef]

191. Yin, L.; Ma, H.; Ge, X.; Edwards, P.A.; Zhang, Y. Hepatic hepatocyte nuclear factor 4alpha is essential for maintaining triglyceride and cholesterol homeostasis. Arter. Thromb. Vasc. Biol. 2011, 31, 328-336. [CrossRef] [PubMed]

192. Lee, D.H.; Park, S.H.; Ahn, J.; Hong, S.P.; Lee, E.; Jang, Y.J.; Ha, T.Y.; Huh, Y.H.; Ha, S.Y.; Jeon, T.I.; et al. Mir214-3p and Hnf4a/Hnf4alpha reciprocally regulate Ulk1 expression and autophagy in nonalcoholic hepatic steatosis. Autophagy 2021, 17, 2415-2431. [CrossRef] [PubMed]

193. Preitner, N.; Damiola, F.; Lopez-Molina, L.; Zakany, J.; Duboule, D.; Albrecht, U.; Schibler, U. The orphan nuclear receptor REV-ERBalpha controls circadian transcription within the positive limb of the mammalian circadian oscillator. Cell 2002, 110, 251-260. [CrossRef]

194. Feng, D.; Liu, T.; Sun, Z.; Bugge, A.; Mullican, S.E.; Alenghat, T.; Liu, X.S.; Lazar, M.A. A circadian rhythm orchestrated by histone deacetylase 3 controls hepatic lipid metabolism. Science 2011, 331, 1315-1319. [CrossRef] [PubMed]

195. Lazar, M.A.; Hodin, R.A.; Darling, D.S.; Chin, W.W. A novel member of the thyroid/steroid hormone receptor family is encoded by the opposite strand of the rat c-erbA alpha transcriptional unit. Mol. Cell Biol. 1989, 9, 1128-1136. [CrossRef] [PubMed]

196. Forman, B.M.; Chen, J.; Blumberg, B.; Kliewer, S.A.; Henshaw, R.; Ong, E.S.; Evans, R.M. Cross-talk among ROR alpha 1 and the Rev-erb family of orphan nuclear receptors. Mol. Endocrinol. 1994, 8, 1253-1261. [CrossRef] [PubMed]

197. Yin, L.; Wu, N.; Curtin, J.C.; Qatanani, M.; Szwergold, N.R.; Reid, R.A.; Waitt, G.M.; Parks, D.J.; Pearce, K.H.; Wisely, G.B.; et al Rev-erbalpha, a heme sensor that coordinates metabolic and circadian pathways. Science 2007, 318, 1786-1789. [CrossRef]

198. Raghuram, S.; Stayrook, K.R.; Huang, P.; Rogers, P.M.; Nosie, A.K.; McClure, D.B.; Burris, L.L.; Khorasanizadeh, S.; Burris, T.P.; Rastinejad, F. Identification of heme as the ligand for the orphan nuclear receptors REV-ERBalpha and REV-ERBbeta. Nat. Struct. Mol. Biol. 2007, 14, 1207-1213. [CrossRef] 
199. Guillaumond, F.; Dardente, H.; Giguere, V.; Cermakian, N. Differential control of Bmal1 circadian transcription by REV-ERB and ROR nuclear receptors. J. Biol. Rhythm. 2005, 20, 391-403. [CrossRef]

200. Kim, Y.H.; Lazar, M.A. Transcriptional Control of Circadian Rhythms and Metabolism: A Matter of Time and Space. Endocr. Rev. 2020, 41. [CrossRef]

201. Huang, G.; Zhang, F.; Ye, Q.; Wang, H. The circadian clock regulates autophagy directly through the nuclear hormone receptor Nr1d1/Rev-erbalpha and indirectly via Cebpb/(C/ebpbeta) in zebrafish. Autophagy 2016, 12, 1292-1309. [CrossRef]

202. Toledo, M.; Batista-Gonzalez, A.; Merheb, E.; Aoun, M.L.; Tarabra, E.; Feng, D.; Sarparanta, J.; Merlo, P.; Botre, F.; Schwartz, G.J.; et al. Autophagy Regulates the Liver Clock and Glucose Metabolism by Degrading CRY1. Cell Metab. 2018, 28, 268-281.e264. [CrossRef]

203. Duez, H.; Staels, B. The nuclear receptors Rev-erbs and RORs integrate circadian rhythms and metabolism. Diab. Vasc. Dis. Res. 2008, 5, 82-88. [CrossRef] [PubMed]

204. Zhang, Y.; Fang, B.; Emmett, M.J.; Damle, M.; Sun, Z.; Feng, D.; Armour, S.M.; Remsberg, J.R.; Jager, J.; Soccio, R.E.; et al. GENE REGULATION. Discrete functions of nuclear receptor Rev-erbalpha couple metabolism to the clock. Science 2015, 348, 1488-1492. [CrossRef] [PubMed]

205. Kim, H.J.; Han, Y.H.; Kim, J.Y.; Lee, M.O. RORalpha Enhances Lysosomal Acidification and Autophagic Flux in the Hepatocytes. Hepatol. Commun. 2021, 5, 2121-2138. [CrossRef] [PubMed]

206. Giguere, V. To ERR in the estrogen pathway. Trends Endocrinol. Metab. 2002, 13, 220-225. [CrossRef]

207. Xia, H.; Dufour, C.R.; Giguere, V. ERRalpha as a Bridge Between Transcription and Function: Role in Liver Metabolism and Disease. Front. Endocrinol. 2019, 10, 206. [CrossRef]

208. Misra, J.; Kim, D.K.; Choi, H.S. ERRgamma: A Junior Orphan with a Senior Role in Metabolism. Trends Endocrinol. Metab. 2017, 28, 261-272. [CrossRef]

209. Giguere, V.; Yang, N.; Segui, P.; Evans, R.M. Identification of a new class of steroid hormone receptors. Nature 1988, 331, 91-94. [CrossRef]

210. Giguere, V. Transcriptional control of energy homeostasis by the estrogen-related receptors. Endocr. Rev. 2008, 29, 677-696. [CrossRef]

211. Kim, S.Y.; Yang, C.S.; Lee, H.M.; Kim, J.K.; Kim, Y.S.; Kim, Y.R.; Kim, J.S.; Kim, T.S.; Yuk, J.M.; Dufour, C.R.; et al. ESRRA (estrogen-related receptor alpha) is a key coordinator of transcriptional and post-translational activation of autophagy to promote innate host defense. Autophagy 2018, 14, 152-168. [CrossRef] [PubMed]

212. Seol, W.; Choi, H.S.; Moore, D.D. An orphan nuclear hormone receptor that lacks a DNA binding domain and heterodimerizes with other receptors. Science 1996, 272, 1336-1339. [CrossRef]

213. Kerr, T.A.; Saeki, S.; Schneider, M.; Schaefer, K.; Berdy, S.; Redder, T.; Shan, B.; Russell, D.W.; Schwarz, M. Loss of nuclear receptor SHP impairs but does not eliminate negative feedback regulation of bile acid synthesis. Dev. Cell 2002, 2, 713-720. [CrossRef]

214. Wang, L.; Lee, Y.K.; Bundman, D.; Han, Y.; Thevananther, S.; Kim, C.S.; Chua, S.S.; Wei, P.; Heyman, R.A.; Karin, M.; et al. Redundant pathways for negative feedback regulation of bile acid production. Dev. Cell 2002, 2, 721-731. [CrossRef]

215. Zhang, Y.; Hagedorn, C.H.; Wang, L. Role of nuclear receptor SHP in metabolism and cancer. Biochim. Biophys. Acta 2011, 1812, 893-908. [CrossRef]

216. Byun, S.; Kim, Y.C.; Zhang, Y.; Kong, B.; Guo, G.; Sadoshima, J.; Ma, J.; Kemper, B.; Kemper, J.K. A postprandial FGF19-SHP-LSD1 regulatory axis mediates epigenetic repression of hepatic autophagy. EMBO J. 2017, 36, 1755-1769. [CrossRef] [PubMed]

217. Ma, W.; Cheng, L.S.; Jiang, W.; Wu, S.D. The small heterodimer partner inhibits activation of hepatic stellate cells via autophagy. Adv. Clin. Exp. Med. 2020, 29, 683-693. [CrossRef] 